\title{
Multidimensional Polarization, Social Classes, and Societal Conflict: Evidence from Medieval Towns
}

\author{
Marie-Christine Thaize Challier ${ }^{1}$ \\ ${ }^{1}$ Université Paris 13, Sorbonne Paris Cité, CEPN (UMR-CNRS 7234), CNRS, France \\ Correspondence: Marie-Christine Thaize Challier, Université Paris 13, Sorbonne Paris Cité, CEPN \\ (UMR-CNRS 7234), 99 Avenue J.B. Clément, F-93430 Villetaneuse, France. Tel: 3-314-940-3255. E-mail: \\ m-christine.thaize@wanadoo.fr
}

Received: November 9, 2015 Accepted: December 2, 2015 Online Published: February 2, 2016

doi:10.5539/res.v8n1p53 URL: http://dx.doi.org/10.5539/res.v8n1p53

\begin{abstract}
The paper focuses on the nature of a population distribution (polarized or not) and its possible influence on societal conflict. Despite theoretical and empirical studies on the link between population's polarization and social conflict, the relationship remains in question. Up to now, the role of a multidimensional polarization has been neglected and the determination of social classes by their roles and functions (and not by their resource level) has been ignored. To extend the research, we first define a multidimensional polarization index and approach it empirically through quantitative and qualitative data (often textual data) over a very long period in accordance with the historiographical method. First, this paper refutes the stereotype of a medieval French urban population polarized between rich and poor. Second, over the same period, we build a database of the intensity and occurrence of societal conflict on a sample of twenty-four French towns. The paper finds that over time the low initial degree of the population's polarization continued to decline while societal violence was increasing. Third, whereas polarization is excluded as a determinant of societal conflict, the inter-group heterogeneity measure (or social distance) highlights some relationships. The results show that societal upheavals may be quite connected with the social distance index defined between the high and middle classes; moreover, this social unrest may be greatly related with the index defined between the high and the low classes. By contrast, the results find an outbreak of societal conflicts when social distances between the middle and low classes decrease.
\end{abstract}

Keywords: medieval towns, social classes, multidimensional polarization, social distance, societal conflict

\section{Introduction}

Much research explores potential sources of societal conflict among various peoples of the world. Early empirical studies by political scientists viewed income or wealth distribution as possible element breeding full-blown conflict (e.g., Nagel, 1974; Muller \& Seligson, 1987; Midlarsky, 1988; Muller et al., 1989). However, as the Lichbach's (1989) survey article has shown, the empirical results were for the most part unclear or statistically insignificant (Esteban, Mayoral, \& Ray, 2012, p. 1310). There is no a general consensus regarding the economic literature on inequality and conflict. While some relevant contributions saw that inequalities are related to the outbreak of socio-political violence (e.g., Sen, 1973; Alesina \& Perotti, 1996; Perotti, 1996; Midlarsky, 1999), other pertinent articles found no evidence between inequality and conflict (e.g., Keefer \& Knack, 2002; Fearon \& Laitin, 2003; Collier \& Hoeffler, 2004; Miguel, Shanker, \& Sergenti, 2004; Alexander \& Harding, 2005; Hegre \& Sambanis, 2006).

There was also no consensus on the analytical tools for examining the way in which inequality is associated with conflict. Besides the Gini coefficient and fractionalization indexes mainly used in the aforementioned articles, researchers turned to another measure of inequality, the polarization index. The measure of polarization and its impact on societal turmoil have been the subject of diverse contributions pioneered by Alesina and Rodrick (1994). Such papers consider that a polarized society is characterized by a population either "rich" or "poor", or by a "vanishing" middle class (Quah, 1994, 1996), or a "disappearing middle" (Levy \& Murname, 1992), or a distribution "spread out from the middle", "hollowed out middle" or by a "tendency toward bimodality" (Foster \& Wolfson, 1992; Wolfson, 1994, 1997). They state that a polarized population with a two-spike distribution appears more conflictual than a uniformly distributed population.

Contrary to the inequality concept (or second-order stochastic dominance for mean-normalized distributions), 
polarization allows to differentiate between "convergence" to the global mean and "clustering" around "local means" (Esteban \& Ray, 1994, p. 821). To explore the formation of groups or clusters in a population, Esteban \& Ray (1994) take into consideration the group aspect of inequality and developed the concepts of identification with one's own group and alienation vis-a-vis other groups. These authors define a polarized population by the fact that while the group members think identification with each other, they feel separated from the members of other groups. (About social identity theory, see e.g., Tajfel, 1981, 1982; Tajfel \& Turner, 1986). Income polarization is higher when the population is split into two similarly sized groups defined by intra-group homogeneity and inter-group heterogeneity. Next, Duclos, Esteban, and Ray (2004) expand the theory of Esteban and Ray by scrutinizing the determinants of the polarization variation. In view of the persistence of socio-political conflicts in many parts of the world, Montalvo and Reynal-Queyrol (2005) recently focus on an ethnic polarization measure and supported the idea that polarization may spur violence. They provided evidence that ethnic polarization does better than the fractionalization one to foresee civil turmoil.

Since three decades, the causes of societal violent unrest continue to produce theoretical models and empirical studies. Despite the substantial advances in medieval demography, it does not seem to be any direct research on the connections between the French medieval population distribution and the outbreak of urban societal conflict. Our contribution is not to provide a definitive interpretation of the medieval society in France but rather to focus on a few features and shed light on some relationships explored over a long time horizon.

The aim of this article is to make clear the following questions: Was the medieval French urban population polarized? If this population was polarized, did that polarization caused the societal conflicts that blew up in some French towns in the Middle Ages? If the population was not polarized, did inter-group heterogeneity may cause such conflicts? To do this, the present paper first builds a polarization index through a qualitative research method producing information on the proxies studied. The polarization index is composed of three aggregated indexes referring to social group size, intra-group homogeneity, and inter-group heterogeneity, according to the initial research of Esteban and Ray-ER from now on(1994). Moreover, our polarization index combines economic and social elements as suggested by Duclos, Esteban, and Ray-hereinafter referred as DER (2004), Zhang and Kanbur (2001), and Ostby (2008). In particular, DER (2004, pp. 1758-1760) propose the concept of "social polarization" considering both income and social attributes, as well as the examination of hybrid measures. Our multidimensional polarization index takes into consideration not only the group size and resource level but also social altruism and ethical factors. More specifically, the intra-group homogeneity index defined here gathers intra-group values (e.g., social qualities, capacities, professional and political competences) and intra-group means to implement such values (e.g., principles, rules, norms, procedures, signals, codes, and standards). This index therefore introduces ethical elements and the means to put them into effect. Next, our inter-group heterogeneity index collects the resource level (e.g., property, assets, wealth, or earnings) and the elements of social conditions linked to the recourse of social and charitable organizations and institutions. The multidimensional polarization measure is here established from historical evidence over a part of the Middle Ages (c.1000-c.1399) in the French urban population and society.

Second, and theoretically, the paper constructs an index of societal conflicts taking into account their occurrence and intensity in a database of 24 medieval French towns throughout the same long time period (four centuries). Empirically, for each town, it firstly collects the occurrence of societal commotions and upheavals, which is a quantitative data. Secondly, given that there is no quantitative data on the conflict intensity, it codes qualitative data and transforms them into a distribution to approximate this intensity. At each period and for each town, the product of the occurrence and intensity gives the mass of conflict.

This research builds on two lines of study worth acknowledging. First, the analytical characterization of the polarization measure is based on the initial theoretical research of ER (1994) who focus on a specific polarization definition encompassing group size, intra-group homogeneity, and inter-group heterogeneity. Second, our empirical multidimensional polarization measure is inspired by the recommendation of DER (2004).

The present paper shows that the urban French population would be not polarized at the beginning of the medieval period into account, which contradicts received wisdom. At the end of the period under review, the evolution of the indicators and the increasing middle class reinforce the fact that the population was even more non-polarized. Population's polarization may not therefore explain the outburst of socio-political violence. Subsequently, the paper studies the relationship between societal conflict and the inter-group heterogeneity index (one of the three determinants of the polarization measure), which is approximated by economic and social factors. The results find that increasing societal conflicts are quite connected with this index when the latter is defined between the high and middle classes, while are greatly associated with the index evaluated between the high and low classes. However, by contrast, the results point to a decrease of the inter-group heterogeneity index 
between the middle and low classes when socio-political turmoil increases. This negative relationship within the urban population is also observed today in many localities in France, Europe, and worldwide.

The article is organized as follows. The next section introduces the literature review and provides motivation for the theoretical approach. Section 3 summarizes the area under review. Section 4 develops the analytical framework and characterizes the variables and the distributional indexes. Section 5 presents the main results and the discussion. Section 6 recaps the key insights and concludes by exploring issues for future research. The Appendix displays the full details of historical evidence, including the rating of the indexes and their indicators.

\section{Literature Review and Theoretical Background}

The term "polarization" is used in many fields. In economic sciences, many scholars try to clarify measures of polarization. Such measures are classified into two families (e.g., Esteban \& Schneider, 2008, p. 133). A first family deals with the process by which a distribution becomes bi-polar, the threshold between the two groups being the median income of the distribution. This family has interpreted polarization as the disappearance of mass at the center of a distribution or, through time, the increasing distance between various points (e.g., Foster \& Wolfson, 1992; Levy \& Murname, 1992; Quah, 1994, 1997; Wolfson, 1994, 1997; Beach \& Slotsve, 1996; Alesina \& Spolaore, 1997; Jones, 1997; Wang \& Tsui, 2000). A second family of polarization measures takes into account the formation of any arbitrary number of groups (or poles). Such measures have been suggested by ER (1994) for discrete distributions, DER (2004) for continuous distributions, Zhang and Kanbur (2001) for a hybrid measure between polarization and inequality (their polarization index is the intra-group inequality/inter-group inequality ratio), and Montalvo and Reynal-Querol (2005) although the latter ignore intergroup distance. Finally, from the thematic point of view, while research increasingly deals with ethnic polarization (e.g., Alesina \& La Ferrara, 2005; Montalvo \& Reynal-Querol, 2005; Esteban et al., 2012), we focus on social polarization which deserves further study.

In the context of medieval population, our first step is a clear and workable definition of social polarization. Given our empirical background, the more relevant definition and characterization are suggested by ER (1994) and DER (2004). In fact, ER (1994) have developed the notions of identification with one's own group and alienation vis-a-vis others to characterize the polarization of a population. First, ER (1994, p. 830) suggest that an individual feels a sense of identification with other individuals who have similar attributes as him- or herself. They have therefore presumed that this identification increases with the number of individuals possessing similar attributes, i.e., with the population in the income class. Thus identification refers to intra-group homogeneity. Second, an individual feels alienation from others who are far away, as when there is a (social or income) distance. Alienation (or division) deals with inter-group heterogeneity. The authors have thus stated the following definition. The polarization of a distribution of attributes must have three basic conditions: (i) a high degree of intra-group homogeneity; (ii) a high degree of inter-group heterogeneity; and (iii) a small number of significantly-sized groups (ER, 1994, p. 824). Put differently, polarization is linked to the alienation that groups feel against each other, this alienation been relied by concepts of identification and group cohesion. Polarization reaches a maximum when the society is bi-polar, i.e., divided into two groups of equal size. Under a bi-polar distribution the likelihood of conflict is seen to be maximized. These authors state the axiom that "the disappearance of a "middle class" into the "rich" and "poor" categories may increase polarization" (ER, 1994, p. 833). "For given income classes and total population, the distribution that assigns half the population to the lowest income class and the remainder to the highest income class is more polarized than any other distribution" (ER, 1994, p. 837). Moreover, they put forward that income polarization is greatest when the population is bunched into two similarly sized groups characterized by intra-group homogeneity and inter-group heterogeneity.

DER (2004) state that a greater income polarization between two income distributions results from: an increased alienation (i.e., an increase in income distances), an increased identification (i.e., when an already highly-populated group become larger at the expense of the less populated one), and a reinforcement of such effects. The reinforcement occurs when the income distance between two groups increases with the size of the group experiencing an increase in identification (DER, 2004, pp. 1747-1748). In other words, the reinforcement corresponds to the case where the already more populated group becomes more populated (increased identification) and moves away from the less populated group (increased alienation) becoming either richer or poorer. By contrast, a counterbalance occurs when the group who becomes richer or poorer becomes also less populated. Finally DER (2004, p. 1760) conclude that it is necessary to consider intermediary (or hybrid) cases between "pure income polarization" (where only income and wealth matter) and "pure social polarization" (in which income and wealth play no role, and where only social attributes matter). They propose the notion of "social polarization" when both income and social attributes matter. Among the possible forms of social 
polarization, they suggest to take into account social polarization with income-mediated identification as well as social polarization with income-mediated alienation. In the first case, identification is income mediated, not only by group membership, but also by income similarities (i.e., two individuals belong to the same group and have income similarities). In the second case, alienation is income mediated when two individuals belong to different groups and possess different levels of income. Thereby groups have now only a separating function: they are necessary (but not sufficient) for intra-group homogeneity, and they are also necessary (but not sufficient) for inter-group heterogeneity (DER, 2004, p. 1760).

Theoretically, when the cost of conflict is low, Esteban and Ray (2008) show that the intensity of conflict is positively related to the degree of polarization. Moreover, polarization seems significantly related to the incidence of conflict (Montalvo \& Reynal-Querol, 2005) but weakly connected with the onset of conflict (Schneider \& Wiesehomeier, 2008).

\section{Study Area: Period and Sample Description}

In accordance with the historiographical method we observe the relationships over the long term. In particular, we collect and reshape the information given by original historical studies in a longitudinal form, the period under review covering the High Middle Ages $\left(11^{\text {th }}-13^{\text {th }}\right.$ centuries $)$ and overlapping a portion ( $14^{\text {th }}$ century) of the Late Middle Ages. This time period can be roughly divided into four phases.

- Period 0: Era prior to the first municipalities. It serves as a reference period just before the introduction of the first emancipated municipalities. It stretches from the early eleventh century to the 1070s.

- Period I: Beginning of the urban political rights redistribution. This period is initiated around the 1070 s by a redistribution of political property rights (the "communal emancipation") and ends roughly in the 1170s.

- Period II: Growth, economic uncertainty, and consular development. This period starts in the 1170s on an era of urban expansion (and the peak of the consular movement), as well as demographic, economic, and commercial development. It then knows episodes of economic instability and finishes around the 1270s.

- Period III: Societal conflict: highpoints of societal conflicts. It begins around the 1270s and continued throughout the fourteenth century; its hallmark is the occurrence of significant highpoints of social revolts in some European towns.

As for the population polarization, the appendix offers detailed historical evidence both on social groups and on the proxies of the indicators collected through a qualitative research. (Regarding this method, see, e.g., Berg, 2007). Now, as to societal conflict, we thus focus on a sample of medieval French towns that experienced a redistribution of political property rights initiated by the appearance of the first municipalities from Period I. Two main types of towns are sufficiently well known by historians to be explored in this article: the communes and consulates. Such towns fought against arbitrary seigniorial decision-making and gained a relatively high autonomy vis-à-vis local feudal lords through associations and rationales of legitimation. In fact, territorial rulers (the king, overlords, and great lords) bestowed privileges concerning legal, administrative, economic, and political autonomy (e.g., Le Goff, 1980, pp. 272-273; Chédeville, 1980, pp. 171-174; Fossier, 1992, pp. 247-249, Reynolds, 1977; Pounds, 1994, pp. 244-248; Thaize Challier, 2000, pp. 53-54; 2011, p. 16). As a result of the political property rights redistribution, some towns gained urban liberty - through a collective, delegate, and dismissible power - in particular the right to govern themselves by choosing their own officers and officials. Each of these emancipated towns began a "multiple political unit and base of organization ... in which political relations were often multi-faceted and shifting" (Lantschner, 2015, p. 22). However, despite new political property rights, urban population aspiration to gain local power was often stymied by local rulers and/or central governing units, leading to bursts of social violence. Throughout the period into consideration, did population distribution spark off revolts?

To answer this question, we build a database of towns and gathered evidence of social conflict, the rule being to use historical studies identified as very good data, the latter being understood by historians through original sources such as records related to town charters, royal and seigniorial documents, municipal registers, local chronicles, and accounts among others. Empirically, certain features are missing for some towns making impossible conflict analysis. We thus define a set of conditions to select a reduced sample of towns with complete information, i.e., the proxies of the variables must have been analyzed in detail by historians. Then we choose twelve case studies as for the communes and other twelve ones related to the consulates to cover a variety of socio-political conflicts, some of them erupting into rebellions and uprisings. Communes and consulates into account are different from a geographical point of view and represent a substantial range of historical and political development. 
Communes set up with the consent of the king who widens his authority by this way. They gained the right to choose their own officials and hold their own courts, the legal identity of the communes being enshrined in a collective oath sworn by some inhabitants - a restricted number of dwellers had access to the municipal organization - to foster mutual solidarity. This licensing of communes was limited in time and space: the communal movement occurred around 1070 (beginning of Period I) and was significant throughout the twelfth century. Its expansion came to an end between 1125 and 1233 in a context of "polycentric political order" (Lantschner, 2015, pp. 6-7). It declined from 1318 when some communes asked for the suppression of their communal charter by the time of generalized middle and lower classes discontent throughout Europe. The twelve communes under study were located in the north of France in the following areas: the towns of Amiens, Beauvais, Compiègne, Laon, Noyon, Senlis, Soissons, and St-Quentin in Picardy, the ones of Poitiers in Poitou, Provins in Île-de-France, Sens in Burgundy, and Valenciennes in the northerly France.

From the 1130s, knights founded the first consulates. The legal identity of the consular towns comes from a seigniorial negotiated grant. The collective power was exercised by a college of administrators (consuls) helped by urban representative assemblies (in particular, a consultative consular council, itself requiring a general assembly of inhabitants). Then the consular expansion reached a peak at the end of the $12^{\text {th }}$ century. Finally, according to scholars, many consular towns were suppressed in the $14^{\text {th }}$ century. The twelve consulates under review scattered in the southern France in the following areas. The towns of Agde, Alès, Beaucaire, Carcassonne, Montpellier, Narbonne, and Nîmes were located in Languedoc-Roussillon, the town of Cahors in the south-west, the ones of Foix and Toulouse near the Pyrénées, and lastly the ones of Manosque and Tarascon-sur-Rhône in Provence.

\section{Analytical Framework: Characterization and Distributional Indexes}

\subsection{Multidimensional Polarization of the Population}

A multidimensional polarization index is here defined through some scalar variable factors, in the context of a medieval society. However, without overall statistics, the population's polarization measure cannot be conducted by analyzing standard demographic and historical sources and methods. Since this drawback precludes any attempt to capture polarization through quantitative evidence, in an effort to fill this knowledge gap, we transform information contained in historical studies into qualitative scales. Subsequently, three multidimensional polarization attributes (the number of groups, group size, intra-group homogeneity, and inter-group heterogeneity) are characterized and approached through sources providing enough qualitative information on such variables. The Appendix contains detailed descriptions and structures of the indicators used in the empirical analysis. Now, the following analyzes the variable values construction.

\subsubsection{Number and Size of Groups}

The characterization of the number and size of groups stands out from classical formulations defining social classes through the resource level. In particular, the middle class is traditionally defined either as the set of people owning an income within an interval from $75 \%$ to $125 \%$ of the median (e.g., Thurow, 1987), or as belonging to the second, third and fourth quintiles of the income distribution (Easterly, 2001), or as living inside common bounds across countries (Milanovic \& Yitzhaki, 2002), or possessing a daily revenue varying over an income interval (Banerjee \& Duflo, 2008), among others. By contrast, following the recommendation of DER (2004, p. 1760), we consider that social groups have only a demarcating role. We therefore separate social groups on the basis of social statutes, vocational functions, and not according to their resources. Empirically, both the number and size of groups are directly approximated through historical qualitative details as we will see.

First, as for the number of social groups, the theory of polarization deserves an accurate classification of such groups. The medieval urban population is distributed over the three social classes (higher, middle, and lower), themselves subdivided into groups. Despite considerable historical studies on medieval professions, the analysis of social groups requires development and application. Firstly, we define a class and group distribution taking into account the occupations identified into the Historical International Standard Classification of Occupation (HISCO; Van Leeuwen, Maas, \& Miles, 2002, 2004), as well as the social classes classified into the Historical International Social Class Scheme (HISCLASS; Van Leeuwen \& Maas, 2011). (Obviously, the occupations during the High Middle Ages and the beginning of the Late Middle Ages do not totally cover the HISCO tree of occupational groups. In addition, for the same evident reasons, we can not use the stratification scale HISCAM (Historical CAMSIS; Lambert, Zijdeman, Van Leeuwen, Maas, \& Prandy, 2013)). However, occupation was not the only factor determining social groups. A significant second factor is the social status, i.e., the prestige linked to one's social position, whether relating to ascribed status (due to inherited position) or achieved status 
(acquired by merits or achievements thanks to ability, skill, and knowledge). According to HISCO, the social status offers useful information to code an occupation into its corresponding social class. As a result, given the specificity of the population under study, we then build a six-category classification, using social status and occupation. In other terms, the three social classes $C_{i}(i=1,2,3)$ known in the medieval French towns are now sub-divided into social groups $g_{n}(n=1, \ldots, 6)$ themselves defined by the occupations and statuses of their members (see Appendix A for the group classification, codes, and composition of each social group).

Second, as to the group size of the population under consideration, historical data offer only rudimentary quantitative elements, providing the size of a specific group or category for a particular town or a vocational association. Nevertheless, available qualitative evidence about the group size is informative. Specifically, for an interpretative framework regarding the group size at each period, we transform the historical qualitative information into a qualitative distribution (see Appendix B). The pieces of historical evidence on the number and size of groups for each social class and period on the one hand, and their assessment on the other hand, are detailed in Appendix C. The results about the relative size of social groups are displayed in Table 1.

\subsubsection{Intra-Group Homogeneity}

Social groups frequently have a distinctive lifestyle that defines their group, such signs demarcating insiders and outsiders. These signs are generally both values (identifiable from the outside) and means to maintain or gain these values. Put differently, within a group, the roles (functions and actions) are defined by values - that identify individuals externally - themselves supported by means. Intra-group homogeneity gives the sense of identification between individuals and can be assessed by indicators. Thereby, we approach the intra-group homogeneity index by the two following indicators, the shared values within a group and the shared means implemented by the group to retain or acquire these values.

- Shared values $\left(x_{1}\right)$. We capture the values shared by a group through the following main factors: ethic qualities (based upon moral or vocational attributes and established by authority, custom, or consent), capabilities, capacities, skills, or political/professional rights.

- Shared means $\left(x_{2}\right)$. We approximate the means shared by a group (to maintain or obtain the previous values) through the following factors: (i) internal rules, for instance, prescriptive specifications of behaviours and actions, vocational rules (including the protection of workers' interests), and established procedures; (ii) norms such as authoritative common practices, principles regulating both actions and value judgments, and standards relative to the jobs like the guarantee of production quality; and/or (iii) codes, for example, systems of principles or signals.

For each period $t$ and each group $n$, the intra-group homogeneity index $I\left(g_{n}^{t}\right)$ is hence measured by:

$$
I\left(g_{n}^{t}\right)=\sum_{k} x_{n, k}^{t} ; \quad k=1,2 . ; \quad n=4 \text { at Period } 0 \text { and } n=6 \text { at Periods I and II. }
$$

Equation (1) determines the intra-group homogeneity index whose construction has needed the following three tasks. First, we establish a qualitative scale for each indicator defined by Equation (1). Concretely, we categorize shared values and shared means into six types. Second, we set a quantitative scale corresponding to the previous qualitative scale in order to sum the indicators and thus obtain the intra-group homogeneity index. Third, we collect qualitative historical evidence that could be used for each indicator of this index (see Appendix D). Here, each decile is not quantitative but notional. Moreover, each group is examined under two levels, or indicators, but the analysis does not rely on a multilevels method stricto sensu. (For details regarding this latter method, see, e.g., Goldstein, 1995; Courgeau, 1998). Table 2 displays the indicators of the shared values and shared means for each social group at each period, and reports the intra-group homogeneity index.

\subsubsection{Inter-Group Heterogeneity}

To comply with the recommendation of DER (2004, pp. 1758-1759) who determine the inter-group heterogeneity index by other characteristics than those defining intra-group homogeneity, we appraise such an index through the following two indicators:

- Resource level, $x_{3}$. This is assessed by levels of property, assets, wealth, or earnings.

- Social conditions, $x_{4}$. These are approximated by the frequency of recourse to social and charitable organizations. This recourse could be seen as an indication of social solidarity or altruism coming from social 
and ethical actions. Such actions encompassed aid granted in voluntary associations (brotherhoods or confraternities), professional ties (craft guilds) or topographical solidarities (quarters), as well as free taking care of sick in hospitals, of needy in hospices, almshouses and other institutions, without forget donations of money granted by some people in favor of these social and charitable institutions (e.g., Vincent, 1994; Dumolyn \& Haemers, 2005, pp. 388-389). Such institutions and organizations worked for the benefit of needy and sick spanning all social groups such as deposed nobles, injured knights, ruined merchants, dismissed officers/officials, unemployed workers. For each period $t$, each group $n$ is defined by the two above-mentioned factors $x_{k}$ :

$$
g_{n}^{t}=f\left(x_{n k}^{t}\right), k=3,4 \text {. }
$$

For each period $t$ and each factor $x_{k}$ we define the partial inter-group heterogeneity (or partial distance) $\varphi^{t}\left(g_{h}, g_{j}\right)$ between the groups $h$ and $j$ by the absolute value of the difference between $x^{t}{ }_{h k}$ and $x_{j k}^{t}$ :

$$
\varphi^{t}\left(g_{h}, g_{j} ; k\right)=\left|x_{h k}^{t}-x_{j k}^{t}\right|, \quad k=3,4 .
$$

For each period $t$, we then define the total inter-group heterogeneity (or total distance) $\Phi^{t}\left(g_{h}, g_{j} ;\right.$ between the groups $h$ and $j$ by the sum of the partial distances given in (2):

$$
\Phi^{t}\left(g_{h}, g_{j} ;=\sum_{k} \varphi^{t}\left(g_{h}, g_{j} ; k\right), k=3,4\right. \text {. (4) }
$$

Equation 3 gives an inter-group heterogeneity index measured by the resource level and social conditions regarding mainly healthcare and assistance (through hospitals, hospices, charitable almsgiving in urban wills, confraternal charity, and charitable generosity of the wealthy). Here also the methodology for constructing this index consists in setting a qualitative scale for the indicators (see Appendix B). Then, using the same methodology as in the preceding paragraph, we gather historical details about such indicators (see Appendices $\mathrm{E}$ and F), which allows us to define the corresponding quantitative scale (see Tables G1 and G2). Finally, we calculate the inter-group heterogeneity index and present it in Table G3.

\subsection{Societal Conflict}

According to Tilly (1978), rebellions or revolts are forms of collective actions where individuals act together in pursuit of common ends, like fairer policy, improvements in everyday life, concessions from the rulers, right to participate in institutions, and abolition of restrictive measure. A part of the literature identifies socio-political conflict with civil war and/or with a number of deaths exceeding a fixed level (e.g., Collier \& Hoeffler, 1998; 2004; Fearon \& Laitin, 2003). Another part measures the number of riots throughout a given period (e.g., Svensson, 1998). Some authors build an aggregate index of societal upheavals projecting in one dimension diverse variables - riot, demonstration against the authority, revolt, and assassination (e.g., Hibbs, 1973; Venieris \& Gupta, 1986; Alesina \& Perotti, 1993).

Analytically, from very long historical perspective, the present paper defines the mass of societal conflicts $(M S C)$ at period $t$ for each town, as the product of their intensity violence $v$ (or the average intensity violence if they are several conflicts on the same period) and their occurrence $\rho$ that is to say:

$$
(M S C)^{t}=v^{t} \times \rho^{t}
$$

The average value of the societal conflict index $\bar{M}^{t}$ for the 24 towns is given by:

$$
\bar{M}^{t}=\sum(M S C)^{t} / \eta ;(\eta=24)(6)
$$

For the evaluation of the mass of societal conflict $(M S C)^{t}$ in the sample of 24 towns, we collect at each period, and for each town, both the intensity and occurrence of conflicts defined as collective actions. To do this, we take into account societal unrest over power and its abuses. We define a classification of the conflict intensity, determine its corresponding quantitative scale (see Table G4 for the rating), and collect the evidence through textual data. (As to this method, see, e.g., Lebart \& Salem, 1994; Guérin-Pace, 1997). The textual data method is made possible thanks an excellent documentary reference offered by a large number of scholars. Then, due to the theoretical framework given by equation (4) and the empirical research, we collect the pieces of evidence on the 
intensity and occurrence of societal conflicts. Subsequently, for each town, we compute the average mass of its conflicts (see Table G5). Finally, the average mass of societal conflicts $\bar{M}^{t}$ for the 24 towns, given by equation (5), is presented in Table 3.

\section{Results}

\subsection{Was the Medieval Urban Population under Study Polarized?}

\subsubsection{Population Distribution before the Political Rights Redistribution: Polarization or Non-Polarization?}

The question at hand concerns the existence or not of a polarized population before the political rights redistribution, i.e., at Period 0. Table 1 presents the evolution of the number and size of groups in such a population.

Table 1. Number of groups and their relative size

\begin{tabular}{llll}
\hline Group Size & Period 0 & Period I & Period II \\
\hline $\mathrm{C}_{1}$ & 1 (Tiny) & 1 (Tiny) & 1 (Tiny) \\
$\mathrm{S}\left(\mathrm{g}_{1 \mathrm{~N} / \mathrm{K}}\right)$ & - & 1 (Tiny) & 1 (Tiny) \\
$\mathrm{S}\left(\mathrm{g}_{1 \mathrm{UB}}\right)$ & & \\
$\mathrm{C}_{2}$ & 4 (Small) & 5 (Small/ Lower-medium) & 6 (Lower-medium) \\
$\mathrm{S}\left(\mathrm{g}_{2 \mathrm{OFF}}\right)$ & 6 (Lower-medium) & 7 (Lower-medium/Medium) & 8 (Medium) \\
$\mathrm{S}\left(\mathrm{g}_{2 \mathrm{SA} / \mathrm{SM}}\right)$ & & & \\
$\mathrm{C}_{3}$ & 14 (Very large) & 10 (Upper-medium) & 7 (Lower-medium/Medium) \\
$\mathrm{S}\left(\mathrm{g}_{3 \mathrm{WP}}\right)$ & - & 1 (Tiny) & 2 (Very small) \\
$\mathrm{S}\left(\mathrm{g}_{3 \mathrm{NWP}}\right)$ & & &
\end{tabular}

Note. When two levels are acceptable for our indicator - e.g., "Very small" (level 2) and "Small" (level 4)-our rule was to define it by the average of such levels (here the indicator is codified at the level 3). Moreover, our distribution takes into account the proportionality between social groups. In fact, given the quantitative coded level, it is easy to see that the sum of each column (i.e., of each period) gives the value 25 , that is, one hundred percent of the population. In other words, from the base Period 0 , one hundred percent of the population at each period is given by the global level 25. Subsequently, the product of the level number by the proportionality factor (here four) gives the percentage of each group in the urban population. For instance, at Period 0 , the group $g_{I N / K}$ of nobles and knights would represent about four percent of the population.

Source: See Appendix C.

First, as regards the initial Period 0, Table 1 shows that this population consisted of four groups varying in size: the "tiny" group $g_{1 N / K}$, the "small" group $g_{2 O F F}$, the "lower-medium" group $g_{2 S A / S M}$, and the "very large" group $g_{3 W P}$. Since the population was not characterized by a small number of similarly sized groups, the condition (iii) of the ER (1994)'s definition is not satisfied. As a result, at Period 0, regarding only the population size (i.e., from a view point demographical), the population under review would be non-polarized.

Second, two other proofs of the non-polarization of this urban medieval population before the redistribution of political rights are the following. On the one hand, the intra-group homogeneity index (defined in Appendix B and calculated through Equation (2)) at Period 0 is "moderate" for the groups $g_{1 N / K}, g_{2 S A / S M}$ and $g_{3 W P}$, and "small" for the group $g_{2 \text { OFF }}$ (see Table 2). On the other hand, at Period 0, the inter-group heterogeneity index 
(evaluated in Appendix B and determined by means of Equation (3)) is "small" between the classes $C_{1}$ and $C_{2}$ (level 2), and "medium" between $C_{2}$ and $C_{3}$ (level 4) as well as classes $C_{1}$ and $C_{3}$ (level 6) (see Table G3). Consequently, at Period 0, the conditions (i) and (ii) of the ER (1994)'s definition are not met. The medieval urban French society into account is not characterized by an important intra-group homogeneity or by strong divisions between social groups. Hence, the evidence supports the conclusion that the population under study at Period 0 would be not polarized, contrary to existing beliefs.

Table 2. Intra-group homogeneity index

\begin{tabular}{|c|c|c|c|}
\hline Intra-group homogeneity index & Period 0 & Period I & Period II \\
\hline \multicolumn{4}{|l|}{$\mathrm{g}_{1 \mathrm{~N} / \mathrm{K}}$} \\
\hline Shared values $\left(\mathrm{x}_{1}\right)$ & 5 & 7 & 8 \\
\hline Shared means $\left(\mathrm{x}_{2}\right)$ & 5 & 7 & 8 \\
\hline $\mathrm{I}\left(\mathrm{g}_{\mathrm{INK}}\right)^{(*)}$ & 10 & 14 & 16 \\
\hline$\%^{(\#)}$ & & $(40)$ & $(14.28)$ \\
\hline \multicolumn{4}{|l|}{$\mathrm{g}_{1 \mathrm{UB}}$} \\
\hline Shared values $\left(\mathrm{x}_{1}\right)$ & - (\&) & 9 & 5 \\
\hline Shared means $\left(\mathrm{x}_{2}\right)$ & - (\&) & 7 & 5 \\
\hline $\mathrm{I}\left(\mathrm{g}_{1 \mathrm{UB}}\right)^{(*)}$ & - & 16 & 10 \\
\hline$\%^{(\#)}$ & & $(-)$ & $(-37.5)$ \\
\hline \multicolumn{4}{|l|}{$\mathrm{g}_{2 \mathrm{OFF}}$} \\
\hline Shared values $\left(\mathrm{x}_{1}\right)$ & 4 & 5 & 5 \\
\hline Shared means $\left(\mathrm{x}_{2}\right)$ & 3 & 7 & 8 \\
\hline $\mathrm{I}\left(\mathrm{g}_{2 \mathrm{OFF}}\right)^{(*)}$ & 7 & 12 & 13 \\
\hline$\%^{(\#)}$ & & $(71.42)$ & $(8.33)$ \\
\hline \multicolumn{4}{|l|}{$\mathrm{g}_{2 \mathrm{SA} / \mathrm{SM}}$} \\
\hline Shared values $\left(\mathrm{x}_{1}\right)$ & 6 & 8 & 4 \\
\hline Shared means $\left(\mathrm{x}_{2}\right)$ & 3 & 5 & 4 \\
\hline $\mathrm{I}\left(\mathrm{g}_{2 \mathrm{SA} / \mathrm{SM}}\right)^{(*)}$ & 9 & 13 & 8 \\
\hline$\%^{(\#)}$ & & $(44.44)$ & $(-38.46)$ \\
\hline \multicolumn{4}{|l|}{$\mathrm{g}_{3 \mathrm{WP}}$} \\
\hline Shared values $\left(\mathrm{x}_{1}\right)$ & 5 & 3 & 3 \\
\hline Shared means $\left(\mathrm{x}_{2}\right)$ & 5 & 3 & 3 \\
\hline $\mathrm{I}\left(\mathrm{g}_{3 \mathrm{WP}}\right)^{(*)}$ & 10 & 6 & 6 \\
\hline$\%^{(\#)}$ & & $(-40)$ & (0) \\
\hline \multicolumn{4}{|l|}{$\mathrm{g}_{3 \mathrm{NWP}}$} \\
\hline Shared values $\left(\mathrm{x}_{1}\right)$ & - (\&) & 1 & 1 \\
\hline Shared means $\left(\mathrm{x}_{2}\right)$ & - (\&) & 1 & 1 \\
\hline $\mathrm{I}\left(\mathrm{g}_{3 \mathrm{NWP}}\right)^{(*)}$ & - & 2 & 2 \\
\hline$\%^{(\#)}$ & & $(-)$ & (0) \\
\hline
\end{tabular}

Notes. $(*)$ For each social group, the index is defined by two indicators rated on the [1-10] scale, as follows: 
"No or Very few" (decile 1); Few" (decile 3); "Some or several" (decile 5); "Quite a few" (decile 7); "Many" (decile 9); "Very many" (decile 10). Given Equation 1, for each social group, the index $\mathrm{I}$ is then measured on the [2-20] scale, with the corresponding "qualitative' scale: "Very small" [2-5]; "Small" [5-8]; "Moderate" [8-12]; "Lower-large" [12-16]; "Large" [16-19]; "Upper-large" [19-20].

(\#) Percentages give the evolution between successive periods.

(\&) At Period 0, the upper-bourgeoisie group $g_{I U B}$ did not exist and the group of nonworking poor $g_{3 N W P}$ had a very insignificant size, as shown in Table 1.

Source: Author's calculation using Appendix D.

\subsubsection{Population Distribution after the Political Rights Redistribution}

Does polarization of the medieval urban population of the study area occur at Period II? First, Table 1 shows three main results concerning the evolution of the number and size of the groups between P0 and PII. (a) It underlines an increase in the number of social groups. In fact, the four-spike distribution at Period 0 becomes a six-spike one at Period II due to the emergence of two extreme groups: the group $g_{1 U B}$ of upper-bourgeois and group $g_{3 N W P}$ of non-working poor. Given this increasing number of non equally sized social groups, the condition (iii) of the ER (1994)'s definition is not satisfied. (b) Over three centuries, it shows not only a growing number of people in the higher class due to the new group $g_{1 U B}$ but also a decreasing number of poor in the group $g_{3 W P}$ although the size of the group $g_{3 N W P}$ increases. (c) Table 1 highlights the increasing size of the social groups $g_{2 O F F}$ and $g_{2 S A / S M}$ constituting the middle class; this class gets bigger as a result of sufficient shared economic growth over Period II. The rise of the middle class reinforces the view of an absence of polarization at Period II. Finally, these three results suggest that the population in question is more unpolarized at Period II than it was at Period 0. Furthermore, it is instructive to note that the larger number of social groups at Period II (from a four-point to a six-point distribution) may increase the fractionalization index, the latter measuring the level to which a society is divided into different groups (e.g., Hirschman, 1964; ER, 2008, p. 166). Fractionalization increases when there are more small groups (e.g., Alesina et al., 2003, p. 177; Esteban \& Schneider, 2008, p. 134). However, Table 1 does not show a tendency to fractionalization because not all groups are smaller since the two groups belonging to the middle class have grown.

Second, Table 2 reports the results of our investigation on the income-mediated intra-group homogeneity index, constituted by two indicators of ethics: values and their means. At Period II, these results do not show the presence of a high degree of intra-group homogeneity among all the groups; this index was "large" for the group $g_{1 N / K}$ (level 16) and "lower-large" for the group $g_{2 \text { OFF }}$ (level 13), but "moderate" for the groups $g_{1 U B}$

(level 10) and $g_{2 S A / S M}$ (level 8), "small" for $g_{3 W P}$ (level 6), and "very small" for $g_{3 N W P}$ (level 2). Such findings are not in line with the condition (i) of the ER (1994)'s polarization definition. Instead of that, they reinforce the fact that the urban population under consideration is also not polarized at Period II, contrary to a stereotype. This non-polarization of the population would be associated to situations more favorable to negotiation and thus to peaceful appropriation of political and economic rights. Yet, the opposite occurs since many conflicts broke out in communes and consulates. What may be the cause of this mass of violence? Since 
population's polarization may not be a determinant of social upheavals, we explore whether a component constituting the polarization definition may explain such turmoils. The evolution of the inter-group heterogeneity index and its link with conflict is the following.

\subsection{Societal Conflict and Inter-Group Heterogeneity}

The observations reported in Table G3 then in Table 3 enable us to examine the relationship between the inter-group heterogeneity (i.e., social distance per se) of the population under review and the societal conflict. Several points emerge from Table G3. First, it shows that the inter-group heterogeneity index between the higher class $C_{1}$ and the middle class $C_{2}$ increases by $100 \%$ from Period 0 to I and continues to rise by $50 \%$ from Period I to II. Concerning the social distance between the groups of the bourgeoisie and the nobility, two antagonistic effects can be noted. On the one hand, one encounters an increase in the "income-mediated social distance" with the upper bourgeois becoming richer than nobles and knights. On the other hand, historical facts clearly show the "status behavior" of such bourgeois; their alliances (i.e., the so-called commandises, pariages, pacts) between themselves and the nobles lead to a decreasing 'status-mediated social distance'. Now, from the middle group's perspective, social distance may rise at Period II due to an increasing "income-mediated social distance" (a portion of the middle class wins more resources) and an increasing "network-mediated social distance" (a proportion of the middle class gets richer through its new role in the urban government as well as through family alliances).

Second, Table G3 shows that the inter-group heterogeneity index between the higher class $C_{1}$ and the lower class $C_{3}$ increases by $108.33 \%$ from Period 0 to I, then by $12 \%$ from Period I to II. This increasing "income-mediated social distance" may be explained by the two following events: the higher bourgeoisie was gradually wealthier than the nobility whereas vulnerable poor moved to the extreme poverty in case of economic crisis.

Third, the inter-group heterogeneity index between the classes $C_{2}$ and $C_{3}$ increases by $112.5 \%$ from Period 0 to I but then falls by $5.88 \%$ between Periods I and II (see Table G3). This decreasing "income-mediated social distance" between $C_{2}$ and $C_{3}$ may be due to the following facts: a portion of the middle class (i.e., the "insecure" middle class in times of economic instability) loses revenues whereas a (low) part of the lower class climbs the social ladder, its interest being aligned with the one of the middle class.

In sum, Table G3 shows that the gap between the higher status on the one hand and the middle and low statuses on the other hand grows while the distance between the middle and lower statuses decreases.

Table 3 displays the societal conflict assessment in the 24 French medieval towns from Period I to III, the turmoil opposing the middle/poor classes, lords and rulers elite, in diverse combinations. It shows that social contentions rise by $51.4 \%$ from Period I to II and by $101.7 \%$ from Period II to III. This conflict evolution is quite associated with a higher level of the inter-group heterogeneity index between the higher and middle classes, whereas is greatly connected with this index defined between the higher and lower classes. This result is in line with the theory showing that higher social distances between classes would ignite huge protests (e.g., Alesina \& Perotti, 1996; Perotti, 1996; Besançon, 2005; for the impact of some kinds of vertical inequality on civil war: e.g., Midlarsky, 1999; and for positive relationship between horizontal social inequality and conflict; e.g., Ostby, 2008). It may be explained through social preferences, particularly the concept of inequity aversion defined as "the preference for fairness and resistance to inequitable outcomes" (e.g., Fehr \& Schmidt, 1999). Inequity adverse agents of the middle and lower classes want to get a "fair share" of surplus between themselves and the 
rich, often leading to inflame the former with anger.

Table 3. Average mass of socio-political conflict $\left(\bar{M}^{t}\right)$ in 24 French towns

\begin{tabular}{llll}
\hline Group Size & Period I & Period II & Period III \\
\hline Mass mean $^{(*)}$ & 9.466 & 14.333 & 28.916 \\
$\%^{(\#)}$ & & $(51.4)$ & $(101.7)$ \\
\hline
\end{tabular}

Notes. $(*)$ See Table G4 for the rating of conflict intensity and Table G5 for the details regarding each town.

(\#) Percentages give the evolution between successive periods.

Source: See Table G5.

However, this result needs to be put into perspective because, from Period I to II, the increase (by 51.4\%) in societal conflict is concomitant with the decrease (by 5.88\%) of the inter-group heterogeneity index between the classes $C_{2}$ and $C_{3}$. This result differs from the empirical ones of Keefer and Knack (2002), Alexander and Harding (2005), and Hegre and Sambanis (2006) who find no evidence between inequalities measure and conflict. In the same way, other researchers show no evidence between vertical economic inequality and internal armed conflict (e.g., Fearon \& Laitin, 2003; Collier \& Hoeffler, 2004). A potential explanation of our result is that the decreasing social distance between the middle and lower classes may increase the demand of redistribution wanted by the middle class for its own benefit; in this sense, inequity aversion is "self-centered" (Fehr \& Schmidt, 1999, p. 819). The middle class, composed of "secure" people dependent on local government subsidies (the officers and officials) and political largesse as well as of "insecure" people dependent on the economic context (artisans and skilled wage-earners), may seek to differentiate from the lower one. Middle class members may strive for the fulfilment of their wishes to gain political power and earn more money. They did not want to see their interests aligned with the ones of the lower class. However, opportunities to rise are often closed off. Consequently, the absence of redistribution in favor of the middle class increases social pressure, rebelliousness and then upheavals. The initial disgruntlement becomes a violent outpouring of discontent exacerbated by food shortages. A decreasing intensity of inter-group heterogeneity may be accepted by the middle statuses until a given level beyond which societal violence blows up.

Furthermore, a detailed review of the historical evidence over the twenty-four towns shows that greedy elite and/or other covetous town councilors bring about townspeople grievances. Rulers' greed takes the form of misappropriation of political rights (or political exclusions) and economic rights (monetary opportunities, poor governance) (see Appendix H). The grievance-rebellion of the ordinary inhabitants appears thus as a form of ideological or justice seeking in response to the greed-based policy of such rulers. Obviously, this area is a desirable future direction to further enhance the understanding of the determinants of societal conflict as developed in the conclusion.

\section{Conclusion}

This paper examines the degree of polarization of a medieval population and analyzes whether it plays some role in the outbreak of societal conflict. The methodology relies on a qualitative research in order to deal in depth with the relationship between the population's polarization and societal unrest. The conclusions drawn from the empirical analysis are the following. First, the paper shows that the stereotype of a medieval urban population polarized between rich and poor would be unambiguously rebutted. Indeed, at the beginning of the period under consideration, and only regarding the population size (i.e., the pure demographic perspective), the population in question appears non-polarized between social groups. Moreover, intra-group homogeneity and inter-group heterogeneity levels reinforce the view that this population would be not polarized at that time. Afterwards, at the end of the period into account, the growth of the middle class strengthens the fact of a non-polarized population. 
Other conclusions suggest that the population was even more "unpolarized" over time.

Second, despite this non-polarization, many societal conflicts blew up in the twenty-four towns into account. Once polarization would not be a factor causing societal upheaval, another objective has been to explore the potential connection between the societal conflict level and a component of our multidimensional polarization measure, i.e. the inter-group heterogeneity index. When this index is defined between the higher and middle classes, the paper finds that it may be quite connected with increasing socio-political conflict; when the index is measured between the higher and lower classes, it may be largely related to the increase of societal conflict. Such positive relationships lend support to other studies (Alesina \& Perotti, 1996; Perotti, 1996; Midlarsky, 1999; Besançon, 2005; Ostby, 2008). By contrast, another new insight we derive is that the outbreak of social violence may be quite connected to the reduction in the social distance between the middle and lower classes. This negative relationship found in the case of the medieval French society occurs today in many European countries. This latter result is a little different from other findings underlining no evidence between conflict and inequalities (Keefer \& Knack, 2002; Collier \& Hoeffler, 2004; Alexander \& Harding, 2005; Hegre \& Sambanis, 2006; Fearon \& Laitin, 2003).

Among the advantages of this research, the following three ones are noticeable. A first benefit of this article resides in the fact that it is a first step in the analysis of the population's polarization in medieval society. In this respect, it has integrated many elements that historical demographers will consider are fundamental to understanding the relationships between medieval population and societal violence. Another strong point is to have built a multidimensional polarization measure combining social and economic components as suggested by DER (2004). Besides the group size, this index matches an intra-group homogeneity index with an inter-group heterogeneity one. The first index is constituted by ethical features like values (e.g., vocational qualities, capabilities, skills, and other political or professional elements) and means supporting such values (e.g., internal rules, norms, principles, signals, practices, standards). The second index is formed by resource level (e.g., property, assets, wealth, earnings) and social conditions connected to social altruism (the frequency of recourse to social and charitable organizations). A third benefit of our research stems from our definition of social classes and groups defined through their statutes, roles and functions in society rather than by their resources; it allows to better understand some relationships. For instance, the fact that the number of people in the middle class grew while the middle-class wealth declined is understandable with our formulation. (By contrast, the weakening of the middle class is usually associated to its impoverishment, and therefore to the passage of individuals from the middle class to the lower one.)

However, this research is of course incomplete because measuring a variable is very difficult due to the lack, insufficiency, and incompleteness of quantitative sources. Nevertheless, to handle this problem, we have gathered other historical evidence as explained in the text and appendix. At least two other points deserve further exploration. First, it would be profitable to separate the two types of towns (communes and consulates) since discrepancies emerged about the form of municipal government and the mode of leaders' selection. As to the electoral system, the distinction between majoritarian rules, proportional rules, and fixed shares, among others (Esteban \& Ray, 2008) could yield significant results concerning their influence on conflict onset and intensity. Second, our results show that increasing societal tensions in the twenty-four towns under study are explained neither by a potential polarization nor by increasing social distance between the higher class on the one hand and the middle and lower classes on the other hand. Increasing social conflicts may be rather linked to the reduction in social distances between the middle and lower classes. Consequently, the analysis may be clarified by a variable that deserves more attention: the rulers' greed. In fact, historical evidence shows that societal urban conflicts burst out because non-benevolent rulers or social elite cause mass licit resistance against objectionable customs or practices, namely upsurge of taxation and favoritism, improper use of taxes, arbitrary policies, abuses on the people's goods and work, embezzlement, falsification of tax registers, logrolling, unfair judging, inappropriate use of collective means, rent-seeking, breach of rights including physical violence, and so on (e.g., Wolff, 1947, p. 447; Dumolyn \& Haemers, 2005, p. 375; Turning, 2009, p. 361; For rent-seeking: e.g. Tullock, 1967; Krueger, 1974; Aidt \& Hillman, 2008).

Rulers' greed often took the form of misappropriation of political and economic rights and people's resistance may develop against predatory (national or local) governments to participate in control over town resources. How rulers' greed and collective grievances against a narrow and unjust group of rulers are linked to each other and what effect this connection has on (past and present) European and worldwide societal conflicts are issues that still need to be more explored. In this respect, in accordance with Esteban and Ray (2011) and Esteban et al. (2012), a distinction must be drawn between conflict over "public goods", e.g., political power, cultural dominance, political rights and freedom — and conflict over "private goods", e.g., specific tax breaks, political 
and administrative positions. These issues, among others, must await future research.

\section{References}

Aidt, T., \& Hillman, A. L. (2008). Enduring rents. European Journal of Political Economy, 24(3), 545-553. http://dx.doi.org/10.1016/j.ejpoleco.2008.04.004

Alesina, A., \& Spolaore, E. (1997). On the number and size of nations. Quarterly Journal of Economics, 113, 1027-1056. http://dx.doi.org/10.1162/003355300555411

Alesina, A., Devleeschauwer, A., Easterly, W., Kurlat, S., \& Wacziarg, R. (2003). Fractionalization. Journal of Economic Growth, 8, 155-194. http://dx.doi.org/10.1023/A:1024471506938

Alesina, A., \& Perotti, R. (1996). Income distribution, political instability, and Investment. European Economic Review, 40, 1203-1228. http://dx.doi.org/10.1016/0014-2921(95)00030-5

Alesina, A., \& Rodrik, D. (1994). Distributive politics and economic growth. Quarterly Journal of Economics, 109(2), 465-490. http://dx.doi.org/10.2307/2118470

Alesina, A., \& La Ferrara, E. (2005). Ethnic diversity and economic performance. Journal of Economic Literature, 43(3), 762-800. http://dx.doi.org/10.1257/002205105774431243

Alexander, M., \& Harding, M. C. (2005). Is Poverty to Blame for Civil War? New Evidence from Nonlinear Fixed Effects Estimation. In Annual Meeting of the American Political Science Association, Washington, D.C.

Arnold, B. (1995). Instruments of Power: The Profile and Profession of Ministeriales within German Aristocratic Society, 1050-1225. In Th. N. Bisson (Ed.), Cultures of Power: Lordship, Status, and Process in Twelfth-Century Europe (pp. 36-55). Philadelphia, PA: University of Pennsylvania Press.

Banerjee, A., \& Duflo, E. (2008). What is middle class about the middle classes around the world? Journal of Economic Perspectives, 22(2), 3-28. http://dx.doi.org/10.1257/jep.22.2.3

Barthélémy, D. (1997). La Mutation de l'an Mil a-t-elle eu lieu? Servage et Chevalerie dans la France des Xime et $X 1^{\text {ème }}$ siècles. Paris, France: Fayard.

Barthélémy, D. (2007). La Chevalerie: de la Germanie Antique à la France du XII ème siècle. Paris, France: Fayard.

Beach, C. M., \& Slotsve, G. A. (1996). Are we becoming Two Societies? Income, Polarization and the Middle Class in Canada. Toronto, Ont: C. D. Howe Institute.

Berg, B. L. (2007). Qualitative Research Methods for the Social Sciences. Boston, MA: Pearson / Allyn \& Bacon.

Berthe, M. (2002). Les élites urbaines méridionales au Moyen Âge (XI ${ }^{\text {ème }}-\mathrm{XV}^{\mathrm{ème}}$ siècles). In Mémoires de la Société Archéologique du Midi de la France (pp. 21-40). Actes des journées d'étude de Toulouse, 19-20 May 2001. Toulouse, France: Société archéologique du Midi de la France.

Besançon, M. I. (2005). Relative resources: Inequality in ethnic wars, revolutions, and genocides. Journal of Peace Research, 42(4), 393-415. http://dx.doi.org/10.1177/0022343305054086

Bouchard, C. B. (1998). Strong of body, brave and noble: Chivalry and society in medieval France. Ithaca, NY: Cornell University Press.

Bouineau, J. (1994). Histoire des institutions. $I^{e r}-X V^{e m e}$ siècle. Paris, France: Editions LITEC.

Chedeville, A. (1980). De la cité à la ville, 1000-1150. In A. Chédeville, G. Duby, J. Le Goff, \& J. Rossiaud (Eds.), Histoire de la France Urbaine (Vol. 2, pp. 30-187). Paris, France: Seuil.

Cohn, S. K. (2009). Lust for liberty. The politics of social revolt in medieval Europe. 1200-1425: Italy, France, and Flanders. Harvard, Cambride, MA: Harvard University Press.

Cohn, S. K. (2012). Popular protest in Late Medieval English towns. Cambridge, MA: Cambridge University Press.

Collier, P., \& Hoeffler, A. (1998). On economic causes of civil war. Oxford Economic Papers, 50(4), 563-573. http://dx.doi.org/10.1093/oep/50.4.563

Collier, P., \& Hoeffler, A. (2004). Greed and grievance in civil war. Oxford Economic Papers, 56(4), 563-595. http://dx.doi.org/10.1093/oep/gpf064 
Contamine, P., Guyot-Jeannin, O., \& Le Jan, R. (2006). Le Moyen Âge: le roi, l'église, les grands, le peuple: 481-1514. Paris, France: Seuil.

Cosman, M. P., \& Jones, L. G. (2008). Handbook to Life in the Medieval World. Vol. 3, Facts on File Library of World History. New York, NY: Facts on File.

Courgeau, D. (1998). New methodological approaches in the social sciences. An overview. Population, An English Selection, 10(1), 1-9.

Derville, A. (2000). La société Française au Moyen Âge. Villeneuve d'Ascq, France: Presses Universitaires du Septentrion.

Dewald, J. (1996). The European nobility. 1400-1800. Cambridge: Cambridge University Press.

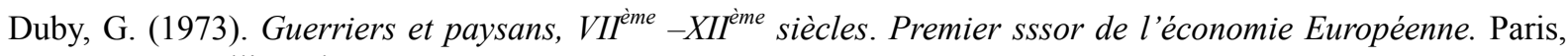
France: Gallimard.

Duby, G. (1973). Hommes et structures du Moyen Âge. Paris, France: Mouton.

Duby, G. (1988). La Société chevaleresque. Paris, France: Flammarion.

Duclos, J.-Y., Esteban, J., \& Ray, D. (2004). Polarization: Concepts, measurement, estimation. Econometrica, 72(6), 1737-1772. http://dx.doi.org/10.1111/j.1468-0262.2004.00552.x

Dumolyn, J., \& Haemers, J. (2005). Patterns of urban rebellion in medieval Flanders. Journal of Medieval History, 31, 369-393. http://dx.doi.org/10.1016/j.jmedhist.2005.08.001

Dutour, T. (2003). La ville médiévale: Origines et triomphe de l'Europe urbaine. Paris, France: O. Jacob.

Dyer, C. (1985). Towns and cottages in $\mathrm{XI}^{\text {th }}$ century England. In H. Mayr-Harting, \& R. I. Moore (Eds.), Studies in Medieval History (Chap. 7, pp. 91-106). New York, NY: The Hambledon Press.

Easterly, W. (2001). The middle class consensus and economic development. Journal of Economic Growth, 6(4), 317-335. http://dx.doi.org/10.1023/A:1012786330095

Epstein, S. A. (2004). Urban society. In D. Abufalia (Ed.), The New Cambridge Medieval History (1198-1300) (Vol. 5, pp. 26-37). Cambridge: Cambridge University Press.

Esteban, J., \& Ray, D. (1994). On the measurement of polarization. Econometrica, 62(4), 819-851. http://dx.doi.org/10.2307/2951734

Esteban, J., \& Ray, D. (2008). Polarization, fractionalization and conflict. Journal of Peace Research, 45(2), 163-182. http://dx.doi.org/10.1177/0022343307087175

Esteban, J., \& Ray, D. (2011). Linking conflict to inequality and polarization. American Economic Review, 101(4), 1345-1374. http://dx.doi.org/10.1257/aer.101.4.1345

Esteban, J., Mayoral L., \& Ray, D. (2012). Ethnicity and conflict: An empirical study. American Economic Review, 102(4), 1310-1342. http://dx.doi.org/10.1257/aer.102.4.1310

Esteban, J., \& Schneider, G. (2008). Polarization and conflict: Theoretical and empirical issues. Introduction to the special issue. Journal of Peace Research, 45(2), 131-141. http://dx.doi.org/10.1177/0022343307087168

Evergates, T. (1995). Nobles and knights in twelfth-century France. In Th. N. Bisson (Ed.), Cultures of Power: Lordship, Status, and Process in Twelfth-Century Europe (pp. 11-35). Philadelphia, PA: University of Pennsylvania Press.

Farmer, S. (2005). Surviving poverty in medieval Paris: Gender, ideology, and the daily lives of the poor. New York, NY: Cornell University Press.

Fearon, J. D., \& Laitin, D. D. (2003). Ethnicity, insurgency, and civil war. American Political Science Review, 97(1), 75-90. http://dx.doi.org/10.1017/S0003055403000534

Fehr, E., \& Schmidt, K. M. (1999). A theory of fairness, competition, and cooperation. The Quarterly Journal of Economics, 114(3), 817-868. http://dx.doi.org/10.1162/003355399556151

Flori, J. (1986). L'essor de la chevalerie. XI-XII ${ }^{\text {ime }}$ siècles. Geneva, Swiss: Edition Droz.

Flori, J. (1998). La chevalerie. Paris, France: Editions Gisserot.

Fossier, R. (1992). Hommes et villages d'Occident au Moyen Âge. Paris, France: Publications de la Sorbonne.

Fossier, R. (1994). La société médiévale. Paris, France: Armand Colin/Masson. 
Foster, J. E., \& Wolfson, M. C. (1992). Polarization and the decline of the middle class: Canada and the US. Mimeo. Nashville, TN: Vanderbilt University.

Given, J. B. (2001). Inquisition and medieval society. Power, discipline \& resistance in Languedoc. Ithaca and London: Cornell University Press.

Goldstein, H. (1995). Multilevel statistical models. London, UK: Edward Arnold.

Guérin-Pace, F. (1997). La statistique textuelle. Un outil exploratoire en sciences sociales. Population (French edition), 52(4), 865-887. http://dx.doi.org/10.2307/1534617

Halphen, L. (1948). L'essor de l'Europe, XI $I^{\text {eme }}$ - XIII ${ }^{\text {eme }}$ siècles. Paris, France: Presses Universitaires de France.

Halphen, L. (1964). Industry and commerce. In A. A. Tilley (Ed.), Medieval France: A companion to French studies (Vol. 5, Chap. 5, pp. 179-197). Cambridge: Cambridge University Press.

Hegre, H., \& Sambanis, N. (2006). Sensitivity analysis of empirical results on civil war onset. Journal of Conflict Resolution, 50(94), 508-535. http://dx.doi.org/10.1177/0022002706289303

Hibbs, D. (1973). Mass political violence. A cross-national causal analysis. New York, NY: Wiley.

Hilton, R. H. (1995). English and French towns in feudal society: A comparative study. Cambridge: Cambridge University Press.

Hirschman, A. (1964). The paternity of an index. American Economic Review, 54(5), 761-762.

Jones, C. I. (1997). On the evolution of the world income distribution. Journal of Economic Perspectives, 11, 19-36. http://dx.doi.org/10.1257/jep.11.3.19

Keefer, P., \& Knack, S. (2002). Polarization, politics and property rights: Links between inequality and growth. Public Choice, 111, 127-154. http://dx.doi.org/10.1023/A:1015168000336

Krueger, A. (1974). The political economy of the rent-seeking society. American Economic Review, 64(3), 291-303.

Kowaleski, M. (1988). The History of urban families in medieval England. Journal of Medieval History, 14, 47-63. http://dx.doi.org/10.1016/0304-4181(88)90016-4

Lambert, P. S., Zijdeman R. L., Van Leeuwen, M. H. D., Maas, I., \& Prandy, K. (2013). The Construction of HISCAM: A stratification scale based on social interactions for historical comparative research. Historical Methods, 46(2), 77-89. http://dx.doi.org/10.1080/01615440.2012.715569

Langlois, Ch. V. (1964). History. In A. A. Tilley (Ed.), Medieval France: A companion to French studies (Vol. 5, Chap. 2, pp. 30-153). Cambridge: Cambridge University Press.

Lantschner, P. (2015). The logic of political conflict in medieval cities. Italy \& the southern Low Countries, 1370-1440. Oxford Historical Monographs. Oxford, UK: Oxford University Press.

Lebart, L., \& Salem, A. (1994). Statistique textuelle. Paris, France: Dunod.

Le Goff, J. (1964). La civilization de l'Occident médiéval. Paris, France: Arthaud.

Le Goff, J. (1980). L'apogée de la France urbaine médiévale. In G. Duby (Ed.), La Ville Médiévale. Des Carolingiens à la Renaissance, in Histoire de la France Urbaine, Tome 2. Paris, France: Seuil.

Leguay, J.-P. (2000). Urban life. In M. Jones (Ed.), The New Cambridge Medieval History: c. 1300-c.1415 (Vol. 6, pp. 102-123). Cambridge: Cambridge University Press.

Lesné-Ferret, M. (1998). The notariate in the consular towns of Septimanian Languedoc (Late twelfth-thirteenth centuries). In K. Reyerson, \& J. Drendel (Eds.), Urban and Rural Communities in Medieval France. Provence and Languedoc, 1000-1500 (pp. 3-21). Boston, MA: Brill.

Levy, F., \& Murname, R.J. (1992). U.S. earnings inequality: A review of recent trends and proposed explanations. Journal of Economic Literature, 30, 1333-1381.

Lichbach, M. I. (1989). An evaluation of 'Does economic inequality breed political conflict?' studies. World Politics, 41(4), 431-470. http://dx.doi.org/10.2307/2010526

Midlarsky, M. I. (1988). Rulers and the ruled: Patterned inequality and the onset of mass political violence. American Political Science Review, 82(2), 491-509. http://dx.doi.org/10.2307/1957397

Midlarsky, M. I. (1999). The evolution of inequality: War, state survival and democracy in comparative perspective. Stanford, CA: Stanford University Press. 
Miguel, E., Shanker, S., \& Sergenti, E. (2004). Economic shocks and civil conflict: An instrumental variables approach. Journal of Political Economy, 112(4), 725-753. http://dx.doi.org/10.1086/421174

Milanovic, B., \& Yitzhaki, S. (2002). Decomposing world income distribution: Does the world have a middle class? Review of Income and Wealth, 48(2), 155-178. http://dx.doi.org/10.1111/1475-4991.00046

Mollat, M. (1978). Les Pauvres au Moyen Âge. Etude sociale. Paris, France: Hachette.

Mollat, M. (1986). The Poor in the Middle Ages: An essay in social history. New Haven, CT: Yale University Press.

Montalvo, J. G., \& Reynal-Queyrol, M. (2005). Ethnic polarization, potential conflict and civil wars. American Economic Review, 95(3), 796-816. http://dx.doi.org/10.1257/0002828054201468

Muller, E. N., \& Seligson, M. A. (1987). Inequality and insurgency. American Political Science Review, 81(2), 425-451. http://dx.doi.org/10.2307/1961960

Muller, E. N., Seligson M.A., Fu, H., \& Midlarski, M.I. (1989). Land inequality and political violence. American Political Science Review, 83, 577-595. http://dx.doi.org/10.2307/1962407

Nagel, J. (1974). Inequality and discontent: A non-linear hypothesis. World Politics, 26(4), 453-472. http://dx.doi.org/10.2307/2010097

Ostby, G. (2008). Polarization, horizontal inequalities and violent civil conflict. Journal of Peace Research, 45(2), 143-162. http://dx.doi.org/10.1177/0022343307087169

Pacaut, M. (1969). Les structures politiques de l'Occident médiéval. Série Histoire Médiévale, Paris, France: Armand Colin.

Perotti, R. (1996). Growth, income distribution and democracy: What the data say. Journal of Economic Growth, 1, 149-187. http://dx.doi.org/10.1007/BF00138861

Pirenne, H. (1898). Villes, marchés et marchands au Moyen Âge. Revue Historique, 67, 59-70.

Pirenne, H. (1969). Histoire économique et sociale du Moyen Âge (1st ed.). Paris, France: Presses Universitaires de France.

Pounds, N. J. G. (1974). An economic history of medieval Europe. New York, NY: Longman Group Limited.

Pounds, N. J. G. (2005). The Medieval City. Greenwood Guides to Historic Events of the Medieval World. Westport, Connecticut, CT: Greenwood Press.

Quah, D. T. (1994). One business cycle and one trend from many disaggregates. European Economic Review, 38(3/4), 605-613. http://dx.doi.org/10.1016/0014-2921(94)90096-5

Quah, D. T. (1996). Twin peaks: Growth and convergence in models of distribution dynamics. The Economic Journal, 106(437), 1045-1055. http://dx.doi.org/10.2307/2235377

Quah, D. T. (1997). Empirics for growth and distribution: Stratification, polarization, and convergence clubs. Journal of Economic Growth, 2(1), 27-59. http://dx.doi.org/10.1023/A:1009781613339

Reyerson, K. L. (1995). Guild. In W. W. Kibler (Ed.), Medieval France: An encyclopedia. London, UK: Routledge.

Reynolds, S. (1977). An introduction to the history of English medieval towns. Oxford, UK: Clarendon Press.

Roncière (de la), C. M. (2000). Poverty, the poor. In A. Vauchez in association with B. Dobson, \& M. Lapidge (Eds.), Encyclopedia of the Middle Ages. Cambridge, UK: James Clarke \& Co Ltd.

Rossiaud, J. (1998). Crises et consolidations, 1330-1530. In Histoire de la France urbaine. Vol. 2, La ville en France au Moyen Âge. Paris, France: Seuil.

Roux, S. (2004). Le monde des villes au Moyen Âge, XI ème-XIV ème siècles. Paris, France: Hachette.

Schneider, G., \& Wiesohomeier, N. (2008). Rules that matter: Political institutions and the diversity-conflict nexus. Journal of Peace Research, 45(2), 183-203. http://dx.doi.org/10.1177/0022343307087176

Sen, A. K. (1973). On economic inequality. Oxford, UK: Clarendon Press.

Stacey, R. (2004). Nobles and knights. In D. Abufalia (Ed.), The New Cambridge Medieval History (c. 1138- c. 1300) (Vol. 5). Cambridge: Cambridge University Press.

Svensson, J. (1998). Investment, property rights and political instability: Theory and evidence. European Economic Review, 42, 1317-1341. http://dx.doi.org/10.1016/S0014-2921(97)00081-0 
Tajfel, H. (1981). Human groups and social categoring: Studies in social psychology. Cambridge: Cambridge University Press.

Tajfel, H. (1982). Social psychology of intergroup relations. Annual Review of Psychology, 33, 1-39. http://dx.doi.org/10.1146/annurev.ps.33.020182.000245

Tajfel, H., \& Turner, J. C. (1986). The social identity theory of intergroup behaviour. In S. Worchel, \& W. G. Austin (Eds.), Psychology of Intergroup Relations. Chicago, IL: Nelson-Hall.

Thaize Challier, M.-C. (2010). Socio-political conflict, social distance, and rent extraction in historical perspective. European Journal of Political Economy, 26(1), 51-67. http://dx.doi.org/10.1016/j.ejpoleco.2009.08.003

Thaize Challier, M.-C. (2011). New towns in medieval France and nature of institutions. Review of European Studies, 3(1), 13-21. http://dx.doi.org/10.5539/res.v3n1p13

Thurow, L. (1987). A Surge in inequality. Scientific American, 256, 30-37. http://dx.doi.org/10.1038/scientificamerican0587-30

Tilly, C. (1978). From mobilization to revolution. Reading, MA: Addison-Wesley Publishing Co.

Tullock, G. (1967). The welfare costs of tariffs, monopolies, and theft. Western Economic Journal, 5(3), 224-232. http://dx.doi.org/10.1111/j.1465-7295.1967.tb01923.x

Turning, P. (2009). 'With teeth clenched and an angry face'; Vengeance, visitors and judicial power in fourteenth-century France. In A. Classen (Ed.), Urban Space in the Middle Ages and the Early Modern Age. Fundamentals of Medieval and Early Modern Culture (pp. 353-371). Berlin, Germany: W. de Gruyter $\mathrm{GmbH} \& \mathrm{Co}$.

Van Leeuwen, M. H. D., Maas, I., \& Miles, A. (2002). HISCO: Historical International Standard Classification of Occupations. Leuven, Belgium: Leuven University Press.

Van Leeuwen, M. H. D., Maas, I., \& Miles, A. (2004). Creating a historical international standard classification of occupations: An exercise in multinational interdisciplinary cooperation. Historical Methods, 37(4), 186-197. http://dx.doi.org/10.3200/HMTS.37.4.186-197

Van Werveke, H. (1966). The rise of the towns. In M. M. Postan, E. E. Rich, \& E. Miller (Eds.), Economic Organization and Policies in the Middle Ages (Vol. 3, pp. 3-41). The Cambridge Economic History of Europe from the Decline of the Roman Empire. Cambridge: Cambridge University Press.

Venieris, Y., \& Gupta, D. (1986). Income distribution and socio-political instability as determinants of savings: A cross-sectional model. Journal of Political Economy, 96, 873-883. http://dx.doi.org/10.1086/261412

Vincent, C. (1994). Les confréries médiévales dans le royaume de France, XIII ${ }^{\text {èe }}-X V^{\text {ème }}$ siècles. Paris, France: Albin Michel.

Wang, Y.-Q., \& Tsui, K.-Y. (2000). Polarization orderings and new classes of polarization indices. Journal of Public Economic Theory, 2(3), 349-363. http://dx.doi.org/10.1111/1097-3923.00042

Wolff, P. (1947). Les luttes sociales dans les villes du Midi Français, XIII ${ }^{\text {ème }}-X{ }^{\text {ème }}$ siècles.” Annales d'Histoire Economique et Sociale, 2, 443-454. http://dx.doi.org/10.3406/ahess.1947.3332

Wolfson, M. C. (1994). When inequalities diverge. American Economic Review, Papers and Proceedings, 94, 353-358.

Wolfson, M. C. (1997). Divergent inequalities: Theory and empirical results. Review of Income and Wealth, 43, 401-421. http://dx.doi.org/10.1111/j.1475-4991.1997.tb00233.x

Zhang, X., \& Kanbur, R. (2001). What difference do polarization measures make? An application to China. Journal of Development Studies, 37(3), 85-98. http://dx.doi.org/10.1080/00220380412331321981 


\section{Appendix}

\section{Appendix A}

\section{Social group classification: group distribution codes and group composition}

We defined social groups through their members' statutes, roles, and functions in society (trades, crafts and occupations) and not by their members' values or income.

\section{$C_{1}$ : Higher class}

- Higher-status people: the group of Nobles and Knights (group $g_{1 N / K}$ ):

- Nobility: both upper category of multi-generational rich and powerful nobles (princes, dukes, counts, viscounts, barons, baronets, and many others powerful landlords) as well as lower category of nobles (lords-castellans and landless nobles)

- Knighthood: both free born knights (milites liberii) belonging to the upper and lower categories of nobles as well as unfree knights, mainly military ministeriales (homines proprii, household servants-knights)

- Higher-status working people: the group of Upper Bourgeois ( $\operatorname{group} g_{1 U B}$ ):

Trade, bank: powerful (guilded) merchants, bankers and other professional money changers and money lenders, grandmaster and well-heeled master craftsmen of major professions, other wealthy proprietors of workshops

Office: royal and municipal leading officials or officers (e.g., kingdom-centred elites, members of representative assemblies), high-powered magistrates, appointed officers and trusted salaried officials, attorneys, proctors, powerful lawyers and notaries

\section{$C_{2}:$ Middle class}

- Medium-status working people: qualified officers and officials (group $g_{2 \text { OFF }}$ ):

- Higher qualified officials and officers: royal or municipal employees (e.g., administrative and bank employees, urban assistants, surveyors, road workers inspectors)

- Medium qualified officials and officers: royal or municipal employees (e.g., town sergeants, town clerks, town criers)

- $\quad$ Seigniorial agents including office ministeriales

- Medium-status working people: skilled artisans and small merchants (group $g_{2 S A / S M}$ ):

- Higher skilled artisans: masters of minor guilds, skilled artisans with corporation competency certification (journeymen), free skilled artisans

- Small merchants, including shopkeepers and farmers living in towns

\section{$C_{3}$ : Lower class}

- Lower-status working people (group $g_{3 W P}$ ):

- lower skilled or unskilled workers: experienced apprentices (teenager workers learning basic techniques), labourers on harbours, low-income workers (manuales, laboratores), low ranking officers (e.g., minor underlings, messengers), lower skilled or unskilled migrant workers

- journeymen and labourers on building sites (skilled workers) in unstable situations

- Servants, street traders, and other workers in income precarious conditions

- Lower-status nonworking people (group $g_{3 N W P}$ ):

- Severely poor people, long-term unemployed

- Needy without financial resources: indigents, have-nots, widows, orphans, and street people (vagabonds, beggars)

- Needy without physical resources: the elderly, cripples, lepers, and other sick

- Professional street criminals, robbers, and other marginal people. 


\section{Appendix B}

\section{Rating of the indexes and their indicators}

- The group size is rated as follows: "tiny" (coded level: 1), "very small" (coded level: 2), "small" (coded level: 4), "lower-medium" (coded level: 6), "medium" (coded level: 8), "upper-medium" (coded level: 10), "large" (coded level: 12), "very large" (coded level: 14). The group size distribution takes into account the proportionality between social groups as seen in the note regarding Table 1.

- The intra-group homogeneity index is determined by two indicators, $x_{1}$ and $x_{2}$, defined as follows:

Indicator $x_{I}$. Shared values (ethic qualities, capabilities, skills, titles, or statuses). Rated as follows: 'The group's members shared ... values': ... "no or very few" (decile 1); ... "few" (decile 3); ... "some or several" (decile 5); ... "quite a few" (decile 7); ... "many" (decile 9); ... "very many" (decile 10).

Indicator $x_{2}$. Shared means (rules, norms, or codes). Rated as follows: 'The group's members shared ... means': ... "no or very few" (decile 1); ... "few" (decile 3 ); ... "some or several" (decile 5); ... "quite a few" (decile 7); ... "many" (decile 9); ... "very many" (decile 10).

- The inter-group heterogeneity index is determined by two indicators, $x_{3}$ and $x_{4}$, defined as follows:

Indicator $x_{3}$. Resource level. Rated as follows: 'There were ... resources (holdings and/or earnings) for a large proportion of the group": "no" (decile 1); "very small" (decile 2); "small" (decile 3); "lower-medium" (decile 4); "medium" (decile 5); "upper-medium" (decile 6); "lower-large" (decile 7); "large" (decile 8); "upper-large" (decile 9); "very large" (decile 10).

Indicator $x_{4}$. Social conditions (mainly healthcare and assistance). Rated as follows: 'The Resort to social and charitable organizations (e.g., hospitals, almshouses, and charitable activities of brotherhoods and confraternities) was ... for a large proportion of the group': ... "permanent or very frequent" (decile 1)...; ... "frequent" (decile 3) ...; ... "regular" (decile 5) ...; ... "occasional" (decile 7) ..; ... "rare" (decile 9) ...; ... "very rare or non-existent" (decile 10)...

\section{Appendix C}

\section{Social group relative size. Historical evidence}

Through historical evidence the social group relative size is the following.

\section{Class $C_{1}$}

- Social group $g_{1 N / K}$

- Period 0. At that time, the documentary evidence has shown that the size of this group $g_{I N / K}$ was tiny (level 1). According to our codes and interpretive framework, this tiny level corresponds to the quantitative "level 1". It therefore refers to about four percent of the population. (For data on the proportion of nobles and knights in some European countries in the Middle Ages, see e.g. Dewald, 1996, chap. 1; Derville, 2000).

- $\quad$ Period 1. Throughout this era, the redistribution of political rights promoted both urban administration and economic exchange. The group $g_{I N / K}$ remained tiny (level 1).

- $\quad$ Period 2. From Period II, the group $g_{I N / K}$ undergoes rearrangement. First, the possessions and legacies of many of the old noble families decreased given the fragmentation of the great estates and the declining real value of their revenues. As a result, around one-half of the nobles failed to remain in the noble group (e.g., Duby, 1973, p. 146). Second, in most areas, the knights adopted the practices of noble succession, which increased the number of small lordships (Stacey, 2004, p. 16). Put differently, the proportion of this category of knights grew drastically and contributed to the expansion of the aristocratic group. As a result of all the above, by and large, the percentage of nobles and knights in the urban population remained constant (i.e., at level 1) also due to the increasing number of inhabitants.

- Social group $g_{1 U B}$

- $\quad$ Period 0. At this time, the upper-bourgeoisie group $g_{I U B}$ did not exist.

- Period I. The social group $g_{I U B}$ emerged. It encompassed well-off corporation masters of major professions, bankers, and high-empowered magistrates (elected magistrates, selecti judices), and successful merchants involved in commerce beyond their city stone walls, transporting goods from one region to another. However this group $g_{I U B}$ was tiny given its relative place in the population (Le Goff, 1980, pp. 278-279; Chédeville, 1980, p. 178; and Derville, 2000, p. 155, p. 162). Its size is thus coded at level 1, which 
corresponds approximately to four percent of the urban inhabitants. (This percentage is fully consistent with the situation in England, among others countries) (e.g., Kowaleski, 1988).

- $\quad$ Period II. From those days, the commercial expansion led to a growing number of affluent upper-bourgeois, such as mercantile elites engaged in long-distance trade and possessing their own workshops, retails outlets, and trading vessels. It was the period of the "increasing professionalization of public service" (Epstein, 2004, p. 34). Self-governed towns contained also an increasing number of inhabitants acting as professionals such as lawyers (pleaders in courts and/or legal advisers), notaries, and professional money changers or lenders. Finally, despite higher absolute number of upper-bourgeois, their proportion remained tiny (level 1) compared with the increasing total population.

\section{Class $C_{2}$}

- Social group $g_{2 \mathrm{OFF}}$

- Period 0. At that time, royal and seigniorial urban officials were assisted by a small group of officials/officers, notably agents acting in the courts or in charge of local administration (e.g., Le Goff, 1980, pp. 278-279; Chédeville, 1980, p. 178; and Derville, 2000, p. 155, p. 162). This small group $g_{2 O F F}$ is thus coded at level 4.

- $\quad$ Period I. The size of the group $g_{2 O F F}$ increased in absolute terms due to the development of royal power and municipal power in this era. On the one hand, by the c.1150, new fiscal and legal regional jurisdictions emerged; they were called bailiwicks in the north and seneschalships in southern provinces (e.g., Derville, 2000, p. 131). Such jurisdictions were subdivided and headed by local royal officials (viguiers or procurators) who themselves oversaw subaltern officials (sous-viguiers, bayles). Each bailiwick and seneschalship included also a variety of bureaucrats and lesser officers (e.g., notaries, sergeants, and proctors) concerned with justice and administration. On the other hand, due to the urban institutional development by c.1070, the group $g_{2 O F F}$ rearranged. It included not only the previous seigniorial agents delegated by territorial rulers for whose benefits they worked (e.g., Derville, 2000, pp. 126-131) but also well-to-do qualified local municipal officials/officers assisted by clerks in the work of municipal administration (Derville, 2000, pp. 155-156). Finally, although this group of municipal royal or seigniorial employees significantly increased in absolute value, it is likely that its proportion weakly grew given the increasing total population. Thereby, this group $g_{2 O F F}$ should have a small or lower-medium size (level 5).

- $\quad$ Period II. This era knew an "increasing professionalization of public service" (Epstein, 2004, p. 34) as already seen, in particular a great profusion of low-ranking officials/officers in the small bureaucracies of town governments or in royal institutions (e.g., clerks of the treasury and of the court, sergeants, and proctors) (e.g., Hilton, 1995, p. 60; Derville, 2000, pp. 219-220). Despite the growing absolute size of the group $g_{2 O F F}$, its relative size should be lower-medium (level 6) given the significant population growth at that time.

- Social group $g_{2 S A / S M}$

- $\quad$ Period 0. The group $g_{2 S A / S M}$ was composed of town craftspeople (artisan producers) and small merchants. They lived side by side; no sharp line separated them. By and large, they formed the social group of the mercatores (e.g., Pirenne, 1898). On the one hand, the free modest artisan producers generally sold their goods super fenestras or in workshops such as weavers, dyers, skinners, clog makers, cutlers, bushel-makers, saddle- and harness makers, and wheelwrights, among others. On the other hand, in this middle class, wholesale merchants owned horse-drawn chariots and/or barges, and travelled all over tracks, waterways and towpaths. This group $g_{2 S A / S M}$ included also some urban peasants involved in farming and orchard cultivation (cultivators, market gardeners) since towns included fields and gardens. Lastly, at that time, craftspeople, merchants, and gardeners/retailers formed a lower-medium social group in size (coded at level 6). (For qualitative data see e.g., Hilton, 1995, pp. 58-60).

- $\quad$ Period I. Due to the political rights redistribution at Period I, the group $g_{2 S A / S M}$ developed. First, skilled craftspeople either would practise into regulated occupations (métiers réglés) whose statuses were defined and administered by royal authorities, either would gather together into self-governed collective associations, the guilds, and thereby exercised sworn occupations (métiers jurés, jurandes). Other artisans should have free occupations (métiers libres) carried out without apprenticeship or specific rules but, in principle, the majority of them belonged to the lower class $C_{3}$. Second, the merchant category was made up of wealthy traders in foodstuffs and established retailers who owned their business. The majority of them had bought the labour power of one or more employees and generally worked alongside the latter (e.g., Dyer, 1985) 
This category included also some urban peasants involved in farming and orchard cultivation (cultivators, market gardeners) since many towns included fields and gardens. Through the qualitative information given by the historical evidence, this group $g_{2 S A / S M}$ increased not only in absolute value but also in relative one. It thus seems reasonable to assess it at the lower-medium/ medium size (level 7) given the increasing total population.

- Period II. In this time, artisan and merchant guilds extended through the development of economic and commercial activities. The group $g_{2} S A / S M$ was mainly composed of artisans selling super fenestras the product of their work (Pirenne, 1898), other shopkeepers, and owners of boats and horses spending most of the year in distant trips. This group increased in absolute value. However, due to the astonishing population growth, and given the evolution of the other groups, it is reasonable to assess the size of $g_{2 S A / S M}$ at the medium level (level 8).

\section{Class $C_{3}$}

- Social group $g_{3 W P}$

- $\quad$ Period 0. At this time, the lower class $C_{3}$ contained varied populations living in ever-changing proportion. This class $C_{3}$ was mainly composed of the group of low-income people and working poor $g_{3 W P}$ such as small free artisans, small shopkeepers, low-qualified employees, servants, handmaids, and unskilled workers (e.g., Roux, 2004, pp. 81-82). Its quantitative weight changed according to the towns but, by and large, at that time, historians have shown that this group $g_{3 W P}$ represented more than fifty percent of the global urban population. This leads us to assess it as very large (level 14).

- $\quad$ Period I. Afterwards, the group $g_{3 W P}$ included temporary workers, skilled/low-skilled or unskilled workers without regular earnings or in a long-term unemployment, laborers on building sites and harbours, apprentices of craft guilds (e.g., Hilton, 1995, p. 61). This group also encompassed small free craftspeople, street traders, tinkers and street hawkers with their mule- or donkey-draw carts, water-carriers, and messengers, and migrants to the towns. These poor were threatened by debt and dispossession. The size of $g_{3 W P}$ changed according to urban prosperity. On the whole, at Period I, it increased in absolute value given the population growth. However, in proportion, this group of low-income people and working poor should reach an upper-medium size (level 10).

- $\quad$ Period II. At this era, although the size of $g_{3 W P}$ increased in absolute, it should decrease in relative value due to the growth of the global population. Historical evidence leads us to evaluate this group at a lower-medium/medium size (level 7).

- Social group $g_{3 N W P}$

- $\quad$ Period 0. The group of nonworking poor $g_{3 N W P}$ had a very insignificant size.

- $\quad$ Period I. Then, gradually, the group $g_{3 N W P}$ encompassed two categories. The first one included townspeople without physical resources (the elderly, sick, cripples, lepers, and other have-nots) and/or financial resources (beggars and vagabonds). Historians have shown an increase in the number of individuals tossed from unskilled, low-skilled or skilled occupation to begging. The second category included professional street criminals such as the swindlers, hustlers, and pickpockets, among others (e.g., Mollat, 1978, pp. 82-83; Derville, 2000, p. 156, p. 190). In proportion, this group $g_{3 N W P}$ should have a tiny size (level 1).

- Period II. In the course of the thirteenth century, towns had a growing number of destitute people as well as lifelong members of the street finally engaged in criminal activities (e.g., Le Goff, 1980, p. 325; and Roux, 2004, p. 82, pp. 140-142). The proportion of these nonworking townspeople also rose and, at Period II, the group $g_{3 N W P}$ should reach a very small size (level 2).

\section{Appendix D}

Intra-group homogeneity index. Historical evidence-

Through historical evidence, the intra-group homogeneity index is the following.

Class $C_{1}$

- Social group $g_{1 N / K}$

- $\quad$ Period 0. At that moment, the upper class was only composed of the distinct categories of nobles (nobiles) and knights (milites). First, nobles were empowered by titles and statuses, themselves determined by an elaborate set of rules, principles and practices. They shared an elaborate set of rules - for instance associated 
with honour, honourable actions, loyalty, and courtesy - and promoted high living (e.g., Dewald, 1996; Bouchard, 1998; Contamine et al., 2006). In other words, long-lasting rules or conventions (about marriage, cultural norms, and language) facilitated self-identification and identification by the others. Second, knighthood was a non-egalitarian corporation from princes and noble knights at the top to lower non-noble knights, horsemen, bachelors and other military servants at the bottom (e.g., Flori, 1998, pp. 25-26). (For details on unfree knighthood, see Arnold, 1995, pp. 41-43; Evergates, 1995, p. 15ff.) Non-noble knights found hard to live up to the noble rules although they tried to imitate the behavior of the upper nobility. At that time, and on the whole, nobles and non-noble knights had therefore quite different values and means, although some of them were common. Put differently, at Period 0, nobles and non-noble knights may share several values and means (decile 5).

- Period 1. Throughout the twelfth century, a growing number of nobles identified themselves knights and felt invested in a value system, the chivalric ideal or ideology (e.g., Barthélémy, 1997, 2007). This code of knightly conduct increasingly emphasized attributes of excellence and ideals of virtues (honour and loyalty) as well as service, commitment, generosity, bravery, and courtly style (e.g., Duby, 1988, pp. 81-180; Bouchard, 1998; Stacey, 2004, pp. 13-17). In the south of France, knights set up consulates and remained the ruling group up to around the first half of the twelfth century; for instance in the towns of Arles (1135-1157), Nîmes (1144), and Avignon (1146), all the consuls were knights (e.g., Le Goff, 1980, pp. 278-279; Chédeville, 1980, p. 178; and Derville, 2000, p. 162). The increased number of nobles in the group $g_{I N / K}$ enlarged the proportion of people having the same values and methods. Consequently, at those times, nobles and knights may have in common quite a few values and means (decile 7).

- $\quad$ Period 2. From Period II, the access to knighthood becoming more and more difficult from around 1240 (e.g., Fossier, 1994, p. 279), knights won an increasing prestige and their attributes were gradually shared by a large proportion of the nobility (e.g., Duby, 1973, pp. 146-147, pp. 325-343; Stacey, 2004, pp. 13-17). Although the two categories of nobles and non-noble knights remained distinct, they thus continue to share quite a few or even many values and means (decile 8).

- Social group $g_{1 U B}$

- $\quad$ Period 0. At this time, the upper-bourgeoisie group $g_{I U B}$ did not exist.

- Period I. The recent group of upper bourgeois encompassed successful merchants and bankers, high-empowered magistrates (elected magistrates, selecti judices), and well-to-do corporation masters of major professions (e.g., Le Goff, 1980, pp. 278-279; Chédeville 1980 p. 178; and Derville, 2000, p. 162). In spite of specificities related to their own activities, the upper bourgeois' identity appears fuelled by their social attributes, particularly their vocational statuses (e.g., Le Goff, 1980; Derville, 2000). Moreover, monetary incentives granted by privilege involvement, served to increase their identity. Historical evidence has shown that the group's members shared not only numerous values such as specific motivations, vocational capacities and skills, but also common means like behavioural norms, social rules, and professional codes. Consequently, on the whole, it is reasonable to assess that the group's members may share many values (decile 9) and only quite a few common means given their specific vocations (decile 7).

Period II. Throughout this era, the upper bourgeois should share less values and means (rules/ norms/codes) due to the following three facts. (i) Auto-selection: many upper bourgeois becoming municipal elites, some of them cheated in different ways, affecting local taxes (from random increase in tax rate and base to favouritism and falsification of tax records), municipal elections (through electoral specificities like exchange of favours and co-options), and other economic areas (public funds loaded at interest, embezzlement, and other forms of corruption). Only a part of wealthy rulers strove to adopt honest behaviours. The relative uniformity found in the previous period thus faded. (ii) Selection and discrimination by the political hierarchy: the kings only ennobled some powerful and influential bourgeois of the rich towns, bestowing more values to such inhabitants. (iii) Selection and discrimination by the vocational hierarchy: the corporations' masters firstly diversified the professional means, each vocational corporation developing its own codes, principles, and rules. Secondly, such masters increasingly classified the professions according to their social importance (the vocations of moneychangers, drapers, and spice merchants being at the top; the more menial, requiring physical force, being at the bottom) (e.g., Derville, 2000, p. 158).

Consequently, and finally, such changes may erode the initial intra-group homogeneity of the group so that upper bourgeois shared less values and means than in the previous period. It will be reasonable to consider that they may share only several values (decile 5) and means (decile 5). 


\section{Class $C_{2}$}

- Social group $g_{2 O F F}$

- Period 0. Before the redistribution of political rights, historical evidence leads us to think that towns were administered by royal and/or seigniorial officials/officers who exercised their activities by sharing more or less some values - professional abilities, titles, and statuses - but without much specific or standardized means, apart from in the legal field. Ruling institutions had "no formal criteria for the selection, training, evaluation, and advancement of administrators" (Given, 2001, p. 19). Subsequently, and globally, it seems likely that these group's members may share few or several values (decile 4) but few means (decile 3) to support such values.

- Period I. Now, municipal or royal qualified officials, together with other administrative and accounting officers, were from different social groups, thereby exacerbating a myriad of values. Moreover, certain agents were engaged in bad practices. This group should therefore share only several professional values (decile 5). In addition, they had to comply with increasingly sophisticated rules, standards or codes (e.g., Halphen, 1964; Given, 2001, pp. 16-19). The group $g_{2 O F F}$ may thus share quite a few means (decile 7).

- $\quad$ Period II. At that time, one witnessed the development of legal and administrative rules and the growing professionalization of municipal service (Epstein, 2004, p. 34). As a result, the group $g_{2 O F F}$ should share quite a few or many means (decile 8). However, certain of these agents were driven by influence activities, departures, and shakedowns- the latter extracted money from people through tax levy, and thereby kept back a significant part of public receipts for their own use (e.g., Duby, 1973, p. 229; Derville, 2000, p. 127). In the end, in spite of the strengthening of municipal rules and urban professional services, the group $g_{2 O F F}$ may share only some values (decile 5).

- Social group $g_{2 S A / S M}$

- Period 0. Before the political property rights redistribution, the group of skilled artisans and small merchants should apparently share similar statuses and certain values like vocational abilities and skills. Moreover, the historical context allows us to appraise that this group shared few rules or codes. Consequently, it appears reasonable to estimate that the group $g_{2 S A / S M}$ should share several or quite a few values (decile 6) and few means (decile 3).

- Period I. At that time, craft and merchant guilds were vocational organizations requiring similar training and certification. Journeymen and apprentices developed their sense of common identity through tasks guaranteeing production quality, among others the creation of a work needing very high standard (the masterpiece). In addition, each member of a guild had obligations and responsibilities to each other. Guilds provided spiritual life (e.g., Le Goff, 1980, pp. 280-283) and social protection via their own associations, often brotherhoods (fraternitates, caritaes) (e.g., Vincent, 1994). As a result, by and large, the group of craftspeople involved in manufacturing and merchants engaged in commerce may share quite a few or many vocational values (decile 8).

Now, as for the means (rules/norms/codes) shared by this group, the great majority of craft guilds had similar vocational rules and norms including the protection of artisans interests or some professional customs (e.g., the certified journeymen may travel to other French or European towns to learn other vocational techniques from foreign masters). However, and first, there was an "increasing level of vocational expertise, and professions became more specialized" (Leguay, 2000, p. 122). Second, not only each guild possessed its own rules or norms but also there was difference in their implementation. In fact, two main types of guilds, and therefore of implementation, developed. (i) Self-enforcement. The sworn occupations (métiers jurés, jurandes) were characterized by collective norms accepted through collective oaths. Such closed guilds had been able to gain the exclusive privileges to self-administer their own business. Sworn corporations were frequent in the merchant guilds or hansas. (ii) Enforcement by the king. In contrast, regulated occupations (métiers réglés) did not have collective oath since their members were subject to royal rules. Given that sworn occupations had self-enforced rules whereas regulated occupations had rules enforced by the king, and given the increasing level of expertise and specialization, it would seem right to estimate that the group $g_{2 S A S M}$ may share several means (decile 5).

- Period II. From the end of the twelfth century, and throughout the period of economic and commercial expansion, the majority of craft and merchant guilds became more autonomous (e.g., Van Werveke, 1966, pp. 31-32; Pirenne, 1969, pp. 145-163; Pacaut, 1969 pp. 273-274; Le Goff, 1980 pp. 280-290; Bouineau, 1994 pp. 306-308; Fossier, 1994, pp. 226-228; Derville, 2000, pp. 158-159; Dutour, 2003, pp. 159-204; and Roux, 
2004, pp. 136-139). However, this increasing autonomy led at least to four effects as regards the values and means shared by the group's members. Firstly, the guilds were increasingly professionally ranked (e.g., Pounds, 2005, p. 114). Given this classification by social ranks, the group should have few common values. Secondly, in the course of the thirteenth century, this group should share few values and means when training and expertise were jealously guarded or when the transfer of skills was only from father to son or son-in-law (e.g., Reyerson, 1995, p. 424). Thirdly, in the real world, craft guilds often kept prices up and limited competition despite the announcement of a collective ethic; meanwhile merchant guilds gradually favored the basic features of capitalism: competition, opportunism, and individualism (Pounds, 2005, p. 113). Fourthly, a geographical ranking of guilds emerged since professions were grouped by quarter or street. Artisan districts were often divided along craft lines, each street merging the workrooms and shops of a specific craft - while merchant districts encompassed shops, multistoried houses, warehouses, inns, and taverns (e.g., Spielvogel, 2008, p. 258). In addition, each craft was geographically classified according to its social and economic weight (Le Goff, 1980, pp. 284-288). These four observations leads us to appraise that the group $g_{2 S A / S M}$ may share only few or some values and means (decile 4) (although there was more common values and means inside each craft or mercantile activity).

\section{Class $C_{3}$}

- Social group $g_{3 W P}$

- Period 0. Before the political property rights redistribution, poor constituted a more or less homogeneous group. It seems appropriate to consider that low-income people and working poor shared some values and means (decile 5).

- $\quad$ Period I. At that time, given the urban development, the group of people having low incomes or living in poverty became more heterogeneous. Some of them were low ranking officers or servants. This group encompassed also street traders and free craftsmen depending on free occupations (métiers libres), i.e., organizations without specific rules. Other group's members were apprentices or casual laborers paid on a daily basis or for a specific task; others endured periods of unemployment or were migrant workers (e.g., Le Goff, 1980, pp. 332-333). This destitute group $g_{3 W P}$ may share few values and rules (decile 3).

- $\quad$ Period II. Self-governed towns and economic expansion increased the number of professions, like the ones of minor subordinate working for municipalities, in crafts or in trade. When the labour market failed to provide work opportunities, some of these low income working townspeople moved into the group of destitute. Such townsfolk had therefore deplorable working conditions and lived in wretched houses or garrets (Leguay, 2000, p. 121). The group $g_{3 W P}$ may thus share few professional values and means (decile $3)$.

- Social group $g_{3 N W P}$

- $\quad$ Period 0. At this time, the group $g_{3 N W P}$ did not exist.

- $\quad$ Period I. The group of nonworking poor emerged throughout this period (e.g., Roux, 2004, chap. 5). This heterogeneous group was composed of destitute people without physical resources (the elderly, cripples, lepers, other sick) and/or without financial resources (long-term unemployed and other have-nots like the street people: vagabonds and beggars), professional street criminals, and other marginal people. By definition, the members of this group had no or very few common values and means (decile 1).

- Period II. As in the previous period, it is expected that the heterogeneous group of needy, marginals, and professional street criminals would share very few values and means (decile 1).

\section{Appendix E}

\section{Inter-group heterogeneity. Indicator $x_{3}$ (resource level). Historical evidence}

Through historical evidence, the indicator $x_{3}$ (resource level) of the inter-group heterogeneity is the following.

\section{Class $C_{1}$}

- Social group $g_{1 N / K}$

- $\quad$ Period 0. First, among the category of nobles, the upper nobles enjoyed very large holdings and/or assets through earldoms and baronies (hence, the expected level is the decile 10). Meanwhile, the lower nobles possessed castellanies and other kind of minor seigneuries, therefore a level of resources approaching the large level (decile 8). Finally, the resources of the category of nobles would average the upper-large level 
(decile 9).

Second, among the category of non-noble knights, the subcategory embracing the upper (and free) knights would have resources approaching, on average, the upper-medium level (decile 6). On the other hand, the subcategory of the lower (and often unfree) non-noble knights often owned transmissible "fiefs" received in return for their knightly services, i.e., lower-medium resources (decile 4). The resources of the category encompassing non-noble knights are therefore evaluated at the medium level (decile 5).

Finally, the resources of the group $g_{I N / K}$ would fluctuate between the deciles 5 and 9 , thus averaging the lower-large level (decile 7).

- $\quad$ Period 1. First, some noble families had still very large resources (decile 10). In contrast, other nobles lost a part of their fortunes, particularly given the declining real value of their land rents (e.g., Flori, 1986), and owned resources approaching the upper-medium level (decile 6). Consequently, the resources of the nobles are evaluated at the large level (decile 8).

Second, on the one hand, the upper (and free) non-noble knights started to form a lineage and, by and large, may increase their resources to the lower-large level (decile 7). On the other hand, the lower (and often unfree) knights, notably the ministeriales, generally expanded their possessions (e.g., Flori, 1986, pp. 25-30) around the medium level (decile 5). Finally, the resources possessed by knights averaged the upper-medium level (decile 6).

Lastly, in sum, the resources of the group $g_{I N / K}$ ranged between the deciles 6 and 8 , the average approximating the decile 7.

- Period 2. First, as to the category of nobles, a part of the greater noble lineages strengthened their homogeneity and maintained very large holdings and/or assets despite new practices of noble succession (decile 10). However, due to the implementation of such practices, another part of the greater nobles lost a portion of their resources and now possessed only large resources (decile 8). The resources of the upper nobles' subcategory should thus average the upper-large level (decile 9).

In contrast, given the new practices of inheritance, the subcategory of lower nobles failed to preserve their resources and continued to lose possessions in diverse ways (e.g., fragmentation of their estates, decrease in the real value of their land rents). This downward mobility decreased their resources, the latter approaching the medium level (decile 5).

Finally, the resources of the category of nobles would scatter between the deciles 5 and 9 , leading to an average assessed at the lower-large level (decile 7).

Second, regarding the category of knights, historical evidence has shown that the subcategory of the upper knights maintained or even increased their fortunes. It is therefore reasonable to assess their resources between the lower-large level and the upper-large one, the mean being a large level (decile 8).

Now, concerning the subcategory of lower knights (particularly the ministeriales), historians have focused on their social elevation (e.g., Duby, 1973, p. 146; Stacey, 2004, p. 14, p. 16). They grew not only in power and titles - they were now considered free members of the nobility - but also in possessions: presumably, the range of their resources should be between the medium and lower-large levels, with a mean of an upper-medium level (decile 6).

Globally, the resources of knights thus varied between the deciles 6 and 8 , the average being evaluated at the lower-large level (decile 7).

As a result, given the resources of the two categories of nobles and knights, the group $g_{I N / K}$ is assessed at the lower-large level (decile 7).

- Social group $g_{1 U B}$

- $\quad$ Period 0. At this time, the group g ${ }_{I U B}$ did not exist.

- $\quad$ Period I. The upper-bourgeois' group encompassed great officers of the crown as well as successful people of affluent merchant guilds engaged both in local wholesale trade and in large scale trade, often in international commerce - the latter possessing not only vessels trade but also retail shops in their home towns (e.g., Derville, 2000, pp. 139-151; Berthe, 2002, pp. 21-35). These flourishing upper-bourgeois would own large (decile 8 ) holdings and/or assets, the extremes ranging from the lower-large to the upper-large level.

- $\quad$ Period II. At that time, the upper-bourgeoisie group expanded in influence and wealth. In fact, not only 
most of the upper-bourgeois were accepted as noblemen but also inter-marriages between nobles and upper-bourgeois aimed to ennoble the descendants of the latter and maintain the lifestyle of the former. In addition, from c. 1150, local great bourgeois became officers of the crown and gradually were appointed as trusted salaried officials, or at the top, wealthy northern baillifs and southern seneschals (e.g., Stacey, 2004, p. 17).

Finally, as leaders of industry, these successful and well-heeled upper-bourgeois would possess now between large and very large resources, with a mean assessed at the decile 9.

\section{Class $C_{2}$}

- Social group $g_{2 \text { OFF }}$

- Period 0. From historical evidence, the resources are expected to extend from the lower-medium level (decile 4) for the lower category (mainly minor royal officials and seigniorial officers) to the upper-medium level (decile 6) for the upper category (e.g., major officers, elected magistrates) (e.g. Derville, 2000, pp. 131-154). The resources of the group $g_{2 \text { OFF }}$ should therefore average the medium level (decile 5).

- Period I. The group of officers/officials encompassed on the one hand seigniorial agents and office ministeriales who farmed their offices: they kept the profits from the duties in return for a lump sum payment to the royal treasury (Langlois, 1964; Derville, 2000). By and large, the documentary evidence allows us to assess their resources from the upper-medium (decile 6) level to the large (decile 8) one, with a mean assessed at the lower-large level (decile 7). On the other hand, from evidence, it is reasonable to assess the mean of the resources owned by qualified officials/officers at the medium level (decile 5).

As a result, the resources of the group $g_{2 O F F}$ should be evaluated at the upper-medium level (decile 6).

- $\quad$ Period II. At that time, firstly, each town belonging to a bailiwick or seneschalship had a growing number of high-ranking magistrates, state officials, assemblies' representatives, as well as many lower officers including specialized agents and public officials such as notaries, clerks of the treasury, sergeants, and other bureaucrats (e.g., Given, 2001, p. 19; Hilton, 1995, p. 60; Cosman \& Jones, 2008, chap. 3). The resources of both the upper- and lower officers and officials decreased in comparison with the previous period. In fact, and firstly, the range of the resources of the category of seigniorial agents and the one of the upper subcategory may be now from the medium to the lower-large level with an average assessed at the upper-medium level (decile 6). Secondly, the resources of the lower subcategory of this group may range from the small to the medium level, the mean being the lower-medium level (decile 4). Finally, this group $g_{2 O F F}$ may be leaner that it once was; their resources averaged the medium level (decile 5), ranging from the decile 4 to the decile 6 .

- Social group $g_{2 S A / S M}$

- $\quad$ Period 0. At this period, first, skilled craftspeople producers were also part-time merchants who made their income from producing and selling commodities to local people. It is reasonable to consider that such artisans should be lower-medium or upper-medium property owners. The resources of these craftspeople should thus average the medium level (decile 5). Second, full-time merchants (shopkeepers, retail sellers of goods, owners of horse-drawn carriages or small boats) were property owners in their own cities, and sometimes may participate in regional commerce. Their resources should also range from the lower-medium level to the upper-medium one, with a mean assessed at the medium level (decile 5). Lastly, the resources of the group $g_{2 S A / S M}$ should average the medium level (decile 5).

- Period I. This period saw a significant change in production, manufacturing, and trade, as well as the consolidation of guilds. Firstly, on the one hand, a subcategory included free artisans and craft masters who became more and more employees hired by rich masters (e.g., Halphen, 1948). Due to the commercial growth, they may enjoy around upper-medium resources (decile 6). On the other hand, in contrast, workmen like journeymen were artisans paid on short term contracts or day workers depending on the tasks distributed by well-off merchants or wealthy masters. They should possess lower-medium resources (decile 4). Finally, by and large, between the lower-and upper-medium levels, the resources of the subcategory of craftspeople should average the medium level (decile 5).

Secondly, among the subcategory of small merchants, the more modest of them possessed a shop in their home town and did not engender enough surpluses to be devoted in more transaction. In contrast, the more fortunate of them owned many shops or retail outlets and / or participated to trade networks. By and large, the resources of such merchants ranged from the upper-medium to the large levels, with a mean estimated at the lower-large level (decile 7). 
Then, on the whole, the resources of the group $g_{2 S A / S M}$ should average the upper-medium level (decile 6).

- Period II. First, the socio-economic landscape had changed. Qualified artisans, not only journeymen but also small masters, were more and more wage-earners (Halphen, 1964, p. 190). It is reasonable to consider that, according to the craft they exercised and the economic situation, they should possess from lower- to upper-medium resources, with a mean assessed at the medium level (decile 5).

Second, as to the merchant category, thanks to marital alliances and their ability to reinvest in activities, they would own lower-large resources (decile 7), the mean between the upper-medium and large levels.

The group $g_{2 S A / S M}$ would therefore gain, on average, upper-medium resources (decile 6).

\section{Class $C_{3}$}

- Social group $g_{3 W P}$

- Period 0. By definition, the group of low-income working townspeople possessed small resources (evaluated at the notional decile 3 ).

- $\quad$ Period I. In times of activity the members of the group $g_{3 W P}$ (small free artisans, shopkeepers, messengers, low-qualified employees or officials or officers, servants, and other unskilled workers) had low or miserable wages, salaries, or commissions. Historians have also shown that the workers in income precarious conditions were now in a more unstable work situation (e.g., Derville, 2000, p. 190, pp. 218-220; Mollat, 1986; Farmer, 2005). As a result, the group had very small resources (decile 2).

- $\quad$ Period II. Economic growth should benefit the poor by lowering poverty. In fact, the thirteenth century was a period of economic growth with phases of economic instability. Once hiring slowed down, a significant part of the low-income working people lost their job, fell into dire poverty, and sometimes moved into the destitute group $g_{3 N W P}$. Meanwhile, those remaining in this group $g_{3 W P}$ suffered more income precariousness, widespread poverty and vulnerability; they generally lived in hovels or attics (e.g., Le Goff, 1964; Halphen, 1964). Consequently, the group $g_{3 W P}$ had still very small resources (decile 2).

- Social group $g_{3 N W P}$

- $\quad$ Period 0. At this time, the group $g_{3 N W P}$ did not exist.

- Period I. These were lean times for many inhabitants; the group of nonworking poor (indigents, marginals, and other street people) emerged (e.g., Roncières, 2000; Roux, 2004, ch. 5). For diverse causes, these severely poor inhabitants did not participate in the labour force, and thus had no or tiny resources (decile 1).

- $\quad$ Period II. Some people of the group of nonworking poor lived in shacks or shanties while others lived in almshouses or shelters (Leguay, 2000, p. 121). They obviously possessed no or tiny resources (decile 1).

\section{Appendix F}

\section{Inter-group heterogeneity. Indicator $\boldsymbol{x}_{4}$ (social conditions). Historical evidence}

\section{Class $C_{1}$}

- Social groups $g_{1 N / K}$ and $g_{1 U B}$

- Period 0, Period 1, Period 2. Whatever the periods, it is probable that the vast majority of the members of both groups $g_{I N / K}$ and $g_{I U B}$ did not appeal to social and charitable organizations, or, if this was the case, had very rare recourse (decile 10$)$.

Class $C_{2}$

\section{- Social group $g_{2 O F F}$}

- Period 0. At that times, the group $g_{2 O F F}$ should have no or very rare recourse to social and charitable organizations. It is therefore coded at the notional decile 10.

- $\quad$ Period I. Given the historical evidence it is likely that the group of officers/officials $g_{2 O F F}$ generally rarely or occasionally (decile 8 ) had recourse to social and charitable associations.

- $\quad$ Period II. It seems reasonable to consider that the group $g_{2 O F F}$ composed of seigniorial agents, officers and officials occasionally (decile 7) used social and/or charitable organizations.

- Social group $g_{2 S A / S M}$ 
- Period 0. At that times, like the group of officers and officials, the group $g_{2} S_{A S M}$ should have no or very rare recourse to social and charitable organizations (decile 10).

Period I. Non-vocational organizations (generally brotherhoods) developed from the second half of the twelfth century when most guilds did not take care of their own destitute artisans or merchants. (For details, see, e.g. Vincent, 1994; Fossier, 1994 p. 227; Epstein, 2004, p. 33, p. 227). It is reasonable to evaluate that the group of skilled artisans and small merchants occasionally (decile 7) need societies of mutual help.

- Period II. In the context of a wavering economy, brotherhoods and other confraternities were increasingly common in each comitiva quarterii (district confraternity, confrérie de quartier) (e.g., Vincent, 1994, pp. 36-38; Mollat, 1978, p. 126). In times of need, the group of skilled artisans and small merchants occasionally or regularly (decile 6) used such institutions.

\section{Class $C_{3}$}

- Social group $g_{3 W P}$

- Period 0. The group $g_{3} W_{P}$ seems to have rarely or occasionally (decile 8) resorted for social or charitable institutions given that such organizations were infrequent at that time.

- Period I. The guilds loaned different allowances to the neediest and came to the aid of the elderly members, widows, and orphans. However, these societies may give support only until c.1150. As a result, it is expected that the members of the group $g_{3 W P}$ would have regular or occasional (decile 6) recourse to hospitals, brotherhoods, and other confraternal charities when their incomes could not support the members of their household (e.g., Le Goff, 1980, pp. 362-365; Farmer, 2005).

- $\quad$ Period II. The members of the group $g_{3 W P}$, besetted by economic vicissitudes, depended more and more of social and charitable organizations for their livelihood. They were often helped by brotherhoods under the payment of dues; otherwise, they became indigents (e.g., Roux, 2004, p. 82). Historical evidence therefore allows us to estimate that the group $g_{3} W_{P}$ would have regularly or frequently (decile 4) recourse to social and charitable organizations.

- Social group $g_{3 N W P}$

- $\quad$ Period 0. At this time, the group $g_{3 N W P}$ did not exist.

- $\quad$ Period I. Charitable societies were composed of brotherhoods and other confraternal associations whose aim was to distribute food, clothing, and money, and to shelter the sick and migrants. Furthermore, hospitals, charities, almshouses, and leper-houses developed for the needy without physical resources (e.g., Mollat, 1978, p. 83). Indeed, at Period I, the number of these organizations drastically increased by means of numerous charitable initiatives such as the assistance of kings and private funds granted by propertied individuals (lords and other wealthy dwellers) or societies (e.g., the Templars, the Hospitallers) (e.g., Le Goff, 1980, pp. 349-352; Mollat, 1986). In addition, the needy received some support from other forms of charity encompassing the almsgiving (notably in wills) and informal assistance from networks of relatives or friends (e.g., Farmer, 2005, p. 6). By and large, it is reasonable to assess that the group $g_{3 \text { NWP }}$ permanently or very frequently (decile 1) relied for support on social and charitable organisations.

- $\quad$ Period II. One witnessed the "municipalization of assistance" for the urban poor (Rossiaud, 1998; see also Fossier, 1994, p. 155; Le Goff, 1980, pp. 332-333; Roux, 2004, p. 82). Around the end of this period, from 1260 , royal power and many urban governments created and oversaw an increasing number of hospitals, charities and confraternities. Moreover, mendicant orders, parishes, or gifts from wealthy people (through almsgiving and legacies drastically increased in that times (e.g., Le Goff, 1980, pp. 324-330, pp. 349-352; Mollat, 1978, pp. 211-216). It is reasonable to assess that the group $g_{3 N W P}$ was entirely (decile 1) assisted by social and charitable organizations. 


\section{Appendix G}

Table G1. Indicators of resources level $\left(x_{3}\right)$ according to social categories and groups

\begin{tabular}{|c|c|c|c|}
\hline Social groups & Period 0 & Period I & Period II \\
\hline \multicolumn{4}{|l|}{ Group $g_{1 \mathrm{~N} / \mathrm{K}}$} \\
\hline \multicolumn{4}{|l|}{ Category of nobles } \\
\hline Upper nobles (mean) & 10 & 10 & 9 \\
\hline Lower nobles (mean) & 8 & 6 & 5 \\
\hline Mean & 9 & 8 & 7 \\
\hline \multicolumn{4}{|l|}{ Category of knights } \\
\hline Upper knights (mean) & 6 & 7 & 8 \\
\hline Lower knights (mean) & 4 & 5 & 6 \\
\hline Mean & 5 & 6 & 7 \\
\hline Mean & 7 & 7 & 7 \\
\hline Group $g_{\text {IUB }}$ (mean) & - & 8 & 9 \\
\hline \multicolumn{4}{|l|}{ Group $g_{2 \mathrm{OFF}}$} \\
\hline Upper category & 6 & 7 & 6 \\
\hline Lower category & 4 & 5 & 4 \\
\hline Mean & 5 & 6 & 5 \\
\hline \multicolumn{4}{|l|}{ Group $\mathrm{g}_{2 \mathrm{SA} / \mathrm{SM}}$} \\
\hline Artisans & 5 & 5 & 5 \\
\hline Merchants & 5 & 7 & 7 \\
\hline Mean & 5 & 6 & 6 \\
\hline Group $g_{3 \mathrm{WP}} \quad$ (mean) & 3 & 2 & 2 \\
\hline Group g $g_{3 \mathrm{NWP}}($ mean) & - & 1 & 1 \\
\hline
\end{tabular}

Note. $\left.{ }^{*}\right)$ As already seen, the indicator $\left(\mathrm{x}_{3}\right)$ of the resource level is rated through the following notional deciles: 'There were ... resources for a large proportion of the group': "No or tiny" (decile 1); "Very small" (decile 2); "Small" (decile 3); "Lower-medium" (decile 4); "Medium" (decile 5); "Upper-medium" (decile 6); "Lower-large" (decile 7); "Large" (decile 8); "Upper-large" (decile 9); "Very large" (decile 10).

Source: Author's calculation using Appendix E.

Table G2. Indicators of resource level $\left(x_{3}\right)$ and social conditions $\left(x_{4}\right)$ according to social groups and classes

\begin{tabular}{clll}
\hline Class and Indicators & Period 0 & Period I & Period II \\
\hline Higher class : $\mathbf{C}_{\mathbf{1}}$ & & & \\
Resource level: $\mathrm{x}_{3}$ & & 7 & 7 \\
$\mathrm{~g}_{\mathrm{IN} / \mathrm{K}}$ & 7 & 8 & 9 \\
$\mathrm{~g}_{1 \mathrm{UB}}$ & $-(\&)$ & $\mathbf{7 . 5}$ & $\mathbf{8}$ \\
Mean $\mathrm{C}_{1}$ & $\mathbf{7}$ & & \\
Social conditions: $\mathrm{x}_{4}$ & & 10 & 10 \\
$\mathrm{~g}_{1 \mathrm{~N} / \mathrm{K}}$ & 10 & 10 & 10 \\
$\mathrm{~g}_{\mathrm{UBB}}$ & $-(\&)$ & $\mathbf{1 0}$ & 10 \\
Mean $\mathrm{C}_{1}$ & $\mathbf{1 0}$ & & \\
Middle class : $\mathbf{C}_{\mathbf{2}}$ & & & \\
Resource level: $\mathrm{x}_{3}$ & &
\end{tabular}




$\begin{array}{llll}\mathrm{g}_{2 \mathrm{OFF}} & 5 & 6 & 5 \\ \mathrm{~g}_{2 \mathrm{SA} / \mathrm{SM}} & 5 & 6 & 6 \\ \text { Mean } \mathrm{C}_{2} & \mathbf{5} & \mathbf{6} & \mathbf{5 . 5}\end{array}$

Social conditions: $\mathrm{x}_{4}$

$\begin{array}{llll}\mathrm{g}_{2 \mathrm{OFF}} & 10 & 8 & 7 \\ \mathrm{~g}_{2 \mathrm{SA} / \mathrm{SM}} & 10 & 7 & 6 \\ \text { Mean } \mathrm{C}_{2} & \mathbf{1 0} & \mathbf{7 . 5} & \mathbf{6 . 5}\end{array}$

Lower class : $\mathbf{C}_{3}$

Resource level: $\mathrm{x}_{3}$

$\begin{array}{llll}\mathrm{g}_{3 \mathrm{WP}} & 3 & 2 & 2 \\ \mathrm{~g}_{3 \mathrm{NWP}} & -(\&) & 1 & 1 \\ \text { Mean } \mathrm{C}_{3} & \mathbf{3} & \mathbf{1 . 5} & \mathbf{1 . 5}\end{array}$

Social conditions: $\mathrm{x}_{4}$

$\begin{array}{llll}\mathrm{g}_{3 \mathrm{WP}} & 8 & 6 & 4 \\ \mathrm{~g}_{3 \mathrm{NWP}} & -(\&) & 1 & 1 \\ \text { Mean } \mathrm{C}_{3} & \mathbf{8} & \mathbf{3 . 5} & \mathbf{2 . 5}\end{array}$

Note. This table shows the evolution of two indicators $\left(x_{3}\right.$ and $\left.x_{4}\right)$ for three periods, four groups in Period 0 , and six groups in Periods I and II.

(*) See the rating of the resource level indicator $\left(x_{3}\right)$ and the mean for each group, see Table G1.

(\#) Recall that the indicator of social conditions $\left(x_{4}\right)$ is rated on the [1-10] scale as follows: 'the resort to social and charitable organizations (e.g., hospitals, almshouses, and charitable activities of brotherhoods and confraternities) was ... for a large proportion of the group': ... "permanent or very frequent" $($ decile 1$) \ldots ; \ldots$ "frequent" (decile 3) ...; ..."regular" (decile 5) ...; ... "occasional" (decile 7) ...; "rare" (decile 9) ...; ... "very rare or non-existent" (decile 10)...

(\&) The upper-bourgeoisie group $g_{I U B}$ did not exist in Period 0 while the group of nonworking poor $g_{3 N W P}$ had a very insignificant size in Period 0 as shown in the empirical framework.

Source: See Appendix F and Table G1.

Table G3. Inter-group heterogeneity index (partial distances $\varphi^{t}$ and total distances $\phi^{t}$ )

\begin{tabular}{clll}
\hline Inter-group heterogeneity & Period 0 & Period I & Period II \\
\hline between $\mathrm{C}_{1}$ and $\mathrm{C}_{2}$ & & & \\
$\varphi^{\mathrm{t}}\left(\mathrm{C}_{1}, \mathrm{C}_{2}\right)$ & & & \\
$\mathrm{x}_{3}$ & $2^{(\&)}$ & 1.5 & 3.5 \\
$\mathrm{x}_{4}$ & 0 & 2.5 & $\mathbf{6}$ \\
$\phi^{\mathrm{t}}\left(\mathrm{C}_{1}, \mathrm{C}_{2}\right)$ & $\mathbf{2}$ & $\mathbf{4}$ & $(50)$ \\
$\%$ & & $(100)$ & \\
between $\mathrm{C}_{2}$ and $\mathrm{C}_{3}$ & & & 4 \\
$\varphi^{\mathrm{t}}\left(\mathrm{C}_{2}, \mathrm{C}_{3}\right)$ & & & 4 \\
$\mathrm{x}_{3}$ & 2 & 4.5 & $\mathbf{8}$ \\
$\phi^{\mathrm{t}}\left(\mathrm{C}_{2}, \mathrm{C}_{3}\right)$ & $\mathbf{4}$ & 4 & $(-5.88)$ \\
$\%$ & & $\mathbf{8 . 5}$ & \\
between $\mathrm{C}_{1}$ and $\mathrm{C}_{3}$ & & $(112.5)$ & \\
\hline
\end{tabular}




$\begin{array}{rlll}\varphi^{\mathrm{t}}\left(\mathrm{C}_{1}, \mathrm{C}_{3}\right) & & & \\ \mathrm{x}_{3} & 4 & 6.5 & 6.5 \\ \mathrm{x}_{4} & 2 & \mathbf{1 2 . 5} & 7.5 \\ \phi^{\mathrm{t}}\left(\mathrm{C}_{1}, \mathrm{C}_{3}\right) & \mathbf{6} & (108.33) & \mathbf{1 4} \\ \% & & (12)\end{array}$

Note. $(*)$ Given Equation 2, the partial inter-group heterogeneity indexes are defined on the interval [0-9], each of the two socio-economic indicators $x_{3}$ and $x_{4}$ being assessed through notional deciles. Thereby, using Equation 3 , the total inter-group heterogeneity indexes $\phi^{\mathrm{t}}$ are measured on the [0-18] interval and assessed as follows: "Small" [0-4], "Medium" [4-9], "Large" [9-14], and "Very large" [14-18].

(\#) Percentages give the evolution between successive periods.

(\&) For example, this value 2 stems from the absolute value of the difference between the values 7 and 5 reported in the first column and respectively in the third and ninth lines of Table G2, according to Equation (2).

Source: See Table G2.

Table G4. Societal conflict index

Societal conflict index

The socio-political conflict index $(*)$ is determined through notional indices, as follows: 'for each town under the study area and time, there was ...'?

- $\quad$ No socio-political conflict (yet compatible with despotic governance) (decile 0) ${ }^{(\#)}$

- Very Low-intensity socio-political conflict (decile 2):

- Very low disagreement from inhabitants against town rulers or superior authority (king, royal agents, lords)

○ Very low discord from town rulers against superior authority (king, royal agents, lords) or other institutions

- Very low dispute between social groups, or between corporation masters vs journeymen or apprentices

- $\quad$ Low-intensity socio-political conflict (decile 4):

- Low disagreement from inhabitants against town rulers or superior authority

- Low dissension from town rulers against superior authority or other institutions

- Low quarrel between social groups, or between corporation masters $v s$ journeymen or apprentices

- Medium-intensity socio-political conflict (decile 6):

- Moderate social unrest from inhabitants against town rulers or superior authority (e.g., loud claims, moderate protests against judicial sentences, shouts against corrupt justice, uproar as noise of crowd, acts of civil disobedience, civil resistance, riotous assemblies, first rumblings against changes in taxation)

- Moderate dissension from town rulers against superior authority or political units, or other institutions (including conspiracy without any trouble, moderate conflict of jurisdiction)

- Moderate quarrel or dispute between social groups, or between corporation masters $v s$ journeymen or apprentices

- $\quad H i g h$-intensity socio-political conflict (decile 8):

- Non-violent ${ }^{(\&)}$ high fight from inhabitants against town rulers or superior authority (e.g., disobedience to kings, rebellion against the arrogance and violence of aristocrats/oligarchs/ruling social elite, rebellion against the increases in taxes and changes in taxation)

- Non-violent high conflict from town rulers against superior authority or political units or other institutions (e.g., refusal to allow (royal) troops to be billeted with town walls, disobedience to kings, revolt against judicial sentences) 
$\circ \quad$ Non-violent high strife between social groups, or between corporation masters $v s$ journeymen or apprentices (e.g., non-violent but high conflict over wages, working conditions)

○ Other non-violent riot, revolt, insurrection, uprising against economic or political power and its abuses

- Non-violent trespass

○ Non-violent excommunication of inhabitants

- Very High-intensity of socio-political conflict (decile 10):

- Violent ${ }^{(\&)}$ struggle from inhabitants against town rulers or superior authority, or political units, or other (e.g., (war) tax resistance))

- Violent conflict from town rulers against superior authority or other institutions

- Violent dispute between social groups, or between corporation masters $v s$ journeymen or apprentices (disputes over wages and working conditions, bitter struggles)

- Other violent riot, rebellion, revolt, insurrection, uprising

$\circ \quad$ Violent trespass or pillaging

- Violent excommunication of inhabitants

○ Fomented or spontaneous bloody uprising; assassination; fierce repression

Notes. $(*)$ We retained local collective actions, mainly societal unrest and conflict against power and its abuses, but excluded civil law disputes, external conflict between the town and outside actors, the Hundred Years War, the repression and extermination against the Cathars, wars between duchies or counties (e.g., the Burgundian-Armagnac struggle), wars between North and South, and foreign wars.

(\#) The deciles are notional and not quantitative.

(\&) The term "violent" is used when there is at least one death.

Source: Author's assessment uses the literature quoted in the text. See also Cohn $(2009,2012)$.

Table G5. Average mass of societal conflict, $\bar{M}^{t}$ (24 towns)

\begin{tabular}{clll}
\hline Average mass $^{(*)}$ & Period I & Period II & Period III \\
\hline COMMUNES & 16 & 8 & 56 \\
Amiens & 21.999 & 49.999 & 25.999 \\
Beauvais & 4 & 8 & 19.999 \\
Compiègne & 25.999 & 10 & 49.999 \\
Laon & 6 & 34 & 10 \\
Noyon & 16 & 0 & 0 \\
Poitiers & - & 8 & 99.999 \\
Provins & - & 0 & 10 \\
Senlis & 24 & 12 & 19.999 \\
Sens & 12 & 19.999 & 19.999 \\
Soissons & 0 & 16 & 38 \\
St-Quentin & 0 & 10 & 38 \\
Valenciennes & - & 12 & \\
CONSULATES & - & 0 & 43.999 \\
Agde & & & 10 \\
Alès & & & \\
\hline
\end{tabular}




\begin{tabular}{llll}
\hline Beaucaire & - & 16 & 8 \\
Cahors & - & 32 & 20 \\
Carcassonne & - & 18 & 27.999 \\
Foix & - & 0 & 28 \\
Manosque & - & 12 & 18 \\
Montpellier & 16 & 12 & 40 \\
Narbonne & 0 & 0 & 24 \\
Nîmes & 0 & 20 & 28 \\
Tarascon-sur-Rhône & 0 & 30 & 14 \\
Toulouse & 0 & 16 & 44 \\
Average mass & (\#) & 14.333 & 28.916 \\
\hline
\end{tabular}

Notes. $\left({ }^{*}\right)$ See Table G4 for the rating of the socio-political conflict intensity. For each town, the average mass of societal conflicts is the product of the intensity mean by the occurrence, as seen in Equation (4).

(\#) The average mass for the 24 towns is calculated for Period I on the basis of 10 communes given that the towns of Provins and Senlis had no municipality, and on the basis of 5 consulates since the other ones (Agde, Alès, Beaucaire, Cahors, Carcassonne, Foix, and Manosque) had no municipality at Period I.

Source: Database built by the author using historical sources and the rating displayed in Table G4. Then, author's calculation using Equations (4) and (5).

\section{Appendix H}

\section{Rulers' or elite's greed in the sample of towns}

The rulers' or elite's greed collected in the database of the 24 towns is composed of the following elements.

- Misappropriation of political rights (political exclusions)

Refusal to create a municipality, abolition of an existing municipality

Lack of voting rights for the middle and lower classes

Refusal to accept the participation of the middle and lower classes into town councils

- Misappropriation of economic rights

Monetary opportunities

Levying of new (arbitrary) taxes or tolls, tax burden shifted on to the middle and lower classes

Monopolization of economic rights or markets by the ruling group

Labor rents, exactions at work

Poor governance

Mismanagement of the municipalities

Heavy municipal debts

Corruption like embezzlement, cheating, manipulation of currency.

\section{Copyrights}

Copyright for this article is retained by the author(s), with first publication rights granted to the journal.

This is an open-access article distributed under the terms and conditions of the Creative Commons Attribution license (http://creativecommons.org/licenses/by/3.0/). 